\title{
SURFICIAL GEOLOGIC MAP OF CENTRAL AND SOUTHERN NEW JERSEY
}

\author{
By Wayne L. Newell ${ }^{1}$, David S. Powars ${ }^{1}$, James P. Owens ${ }^{2}$, Scott D. Stanford ${ }^{3}$, and Byron D. Stone ${ }^{1}$
}

\section{INTRODUCTION}

The surficial geologic maps of central and southern New Jersey set forth the distribution of a variety of near-surface sedimentary deposits on the Coastal Plain and Piedmont. The textures, bedforms, and lithologies of the surficial deposits and their affinities for particular physiographic settings record the response of Earth's surface processes to changing climates and eustatic forces from the Miocene until modern times. The New Jersey Coastal Plain is the only part of the Atlantic Coastal Plain that was proximal to the southern extent of continental glacial advances during the Pleistocene. Evidence of cold, continental climates and periglacial phenomena are abundantly preserved on the New Jersey Coastal Plain. Quaternary deposits along the marine and estuarine margins of New Jersey record warm, humid-temperate climates during interglacial periods. Thus, the surficial geology of New Jersey includes evidence of sustained cold climates, warm climates, and transitional periods. This report describes the physical and mineralogical attributes of the surficial deposits, interprets the systems of geomorphic processes (environments of deposition) responsible for their origins, and discusses the ages of various assemblages of surficial deposits (see Correlation of Map Units).

The surficial geologic maps and cross sections were compiled from extensive field investigations and new geologic mapping as well as from previous geologic maps of various scales compiled during the last 100 years. Figure 1 shows the sources of information that were integrated and compiled. The surficial deposits on the rocks of the Mesozoic basin in the Piedmont were mapped and described systematically according to criteria used on the surficial geologic map of northern New Jersey (Stone and others, 1995, in press) in order to assure continuity. The correspondence of surficial deposits on the Piedmont with surficial deposits on the Coastal Plain is explained in the Description of Map Units and shown on the Correlation of Map Units.

\section{ACKNOWLEDGMENTS}

The following people assisted in the field, performed laboratory analyses, or provided information and therefore greatly enhanced the compilation of these maps. Assistance in

\footnotetext{
${ }^{1}$ U.S. Geological Survey.

${ }^{2}$ Deceased.

${ }^{3}$ New Jersey Geological Survey.

Manuscript approved for publication May 6, 1998.
}

the field was provided by John S. Wyckoff (formerly of the U.S. Geological Survey (USGS), 1987-1990), John Farnsworth (formerly of the New Jersey Geological Survey, 1985-1988), Mathews Lawrence (a student sponsored by the National Association of Geology Teachers in cooperation with the USGS, summer 1990), and David B. Mason (formerly of the USGS, 1991-1992). Mohammad Huq of the Bangladesh Geological Survey accompanied us in the field during the summer of 1986.

Lloyd Mullikin and Peter J. Sugarman of the New Jersey Geological Survey provided access to a number of borehole logs and support for determining ${ }^{14} \mathrm{C}$ dates and pollen spectra. John Wehmiller of the University of Delaware and his students provided Quaternary age data determined from amino acid ratios of mollusks. Leslie A. Sirkin (Adelphi University) and Gilbert J. Brenner (State University of New York at New Paltz) each analyzed numerous samples for pollen and interpreted the climate change history. Jack A. Wolfe (USGS) examined pollen and leaves from the Miocene Cohansey Formation. Stewart Farrell of Stockton State College contributed to our understanding of the head of the Mullica River basin near Atsion. Christopher Smith and Douglas Wysocki of the U.S. Department of Agriculture Soil Conservation Service and John Tedrow, emeritus professor at Cook College, Rutgers University participated in field discussions of the origins of soils on the landscape, cold climate phenomena, and on the distribution of loess and windblown sand.

Virginia M. Gonzalez, David B. Mason, and Steven G. Van Valkenburg (all formerly of the USGS) aided with the analyses of clay minerals and with heavy-mineral separations. Lauck W. Ward (Virginia Museum of Natural History, formerly of the USGS) examined molluscan assemblages. Carl Koteff (USGS, retired), Janet Radway Stone (USGS), and J. Phillip Schaeffer (USGS, deceased) discussed regional aspects of glacial history, glacial melting, global warming, and periglacial phenomena. J. Stephen Schindler (USGS), Todd D. Hiebel (formerly of the USGS), and David B. Mason (formerly of the USGS) assisted with the layout and compilation of the cross sections and explanatory material for the preceding U.S. Geological Survey Open-File Report (Newell and others, 1995).

Several agencies and a private source provided access to subsurface information which immensely aided subsurface mapping and construction of accurate cross sections. They include the New Jersey Department of Transportation, New Jersey Turnpike Authority, New Jersey Highway Authority (Garden State Parkway), Delaware River and Bay Authority, and Golder Associates.

The maps were critically reviewed by Carl Koteff and Benjamin 
A. Morgan, III (USGS). Peter J. Sugarman, Richard Dalton (New Jersey Geological Survey), Arthur P. Schultz (USGS), and J. Stephen Schindler also reviewed various drafts of the maps.

\section{PHYSIOGRAPHY}

The physiography of the Atlantic Coastal Plain is commonly characterized as an Outer Coastal Plain and an Inner Coastal Plain. The Outer Coastal Plain is a region of low altitude where low-relief terraces are bounded by subtle erosional scarps. The deposits underlying the terraces are commonly Pliocene and Pleistocene marginal-marine sediments. Constructional surface features such as barrier bars, deltas, and dune fields are preserved. The Inner Coastal Plain is commonly higher in altitude and greater in local relief than the Outer Coastal Plain because it was uplifted, weathered, and dissected. Complex surficial deposits cover the slopes of the Inner Coastal Plain and record the erosional events of long exposure. The Fall Line (or Fall Zone) usually marks the boundary between the resistant bedrock of the Piedmont and the unconsolidated sediments of the Coastal Plain. Inner Coastal Plain formations range in age from Early Cretaceous to Miocene. The physiography of the New Jersey Coastal Plain is a compact assemblage of these two subprovinces. Erosional remnants of an Inner Coastal Plain landscape are mostly bordered by marginal-marine and estuarine terraces.

At the Fall Line, the Delaware River turns $90^{\circ}$ to the southwest and discharges into the head of the Delaware River estuary. The narrow tidal portion of the Delaware River estuary follows the inner edge of the Coastal Plain for nearly $100 \mathrm{~km}$ parallel to the strike of the southeast-dipping Cretaceous and Tertiary strata. The tidal river course is deflected again $90^{\circ}$ to the southeast as it enters the Delaware Bay. The drainage of the New Jersey Coastal Plain is divided between (1) river basins that drain the eastward-dipping slopes of Coastal Plain strata directly to the Atlantic Ocean, and (2) river basins which flow across the strike of the Cretaceous and Tertiary strata into the tidal Delaware River and Delaware Bay. The northernmost part of the New Jersey Coastal Plain drains into Raritan Bay.

The New Jersey Coastal Plain can be subdivided into five distinct physiographic units which, in part, show the effects of rock control on geomorphic processes. The physiographic units as characterized in this context include the Central Uplands, the Southern Uplands, the Interior Lowlands, the Interior Plateaus, and the Coastal Lowlands (fig. 2).

The Central Uplands are characterized by highly dissected low hills and broad intervening valleys commonly covered by sand and gravel eroded from adjacent hills. This region is largely underlain by the Miocene Cohansey Formation (Lewis and Kümmel, 1910-1912), a silica-rich sand of fluvial to marginalmarine origin; the Cohansey ranges from 10 to $30+\mathrm{m}$ in thickness where exposed. The Cohansey has been subjected to weathering and erosion since the late middle Miocene (10 Ma). Vegetation ranges from oak and hickory forests to pine and scrub oak forests.

The Southern Uplands are distinguished by broad plains which descend gradually to the southeast. The Southern Uplands are dissected by underfit streams flowing through wide valleys. Deeply weathered, arkosic, fluvial gravels of the Bridgeton Formation underlie the broad plains. The Miocene Bridgeton Formation (Owens and Minard, 1979) has been exposed to weathering and erosion at least since the end of the Miocene.
The wide valleys are cut into the Cohansey Formation and are filled with locally derived surficial deposits. Windblown sediments occurring on the valley sides unconformably overlie the Bridgeton Formation. Deciduous forests and farmlands cover the uplands; pines, scrub oaks, and white cedar swamps occupy the valleys.

The two upland regions are separated for the most part by an extensive area of Interior Lowlands that includes the major watershed of the Mullica River and its tributaries. Other extensive areas included in the Interior Lowlands occur in the Great Egg Harbor River valley and the headwaters of the Rancocas, Toms, and South Rivers. The Interior Lowlands are broad bottomlands and low terraces that are perennially wet from ground-water discharge; small, underfit streams meander through wide flood plains. Bogs, white cedar swamps, and pinescrub oak forests are typical woodlands of the Interior Lowlands. Since colonial times, the area across the Central and Southern Uplands and the Interior Lowlands that is dominated by pinescrub oak forest and white cedar swamps has been loosely known as the "Pine Barrens." Increased concern for the preservation of the Pine Barrens as a unique ecologic area stimulated the formal designation of much of Ocean, Atlantic, Burlington, Cape May, and Cumberland Counties as the "Pinelands," an area of common socio-economic as well as ecologic significance (Berger and Sinton, 1985). As generally understood, the "Pine Barrens" and the "Pinelands" are confined to the outcrop belt of the Miocene Cohansey Formation and extensive surficial deposits derived from the Cohansey Formation.

The Interior Plateaus are low-relief, dissected plains extending from Raritan Bay southwestward along the tidal Delaware River. The plains are underlain by deeply weathered fluvial gravels of the Miocene Bridgeton and Pensauken Formations (Owens and Minard, 1979) that unconformably overlie the Cretaceous and Tertiary strata. Numerous low-gradient stream valleys filled with surficial deposits drain from the Central Uplands across the Interior Plateaus to join with larger streams along the Fall Line and with the Delaware River. Extensive areas are covered with windblown sand. The Interior Plateaus originally were covered with a diverse hardwood forest and meadows, but the region has been a highly productive agricultural region since the earliest European colonization.

The Coastal Lowlands include as many as three scarp-bounded terraces underlain by Quaternary marine and estuarine deposits. Subtle landforms preserved on the surfaces include barrier bars, inlets, tidal deltas, and sand dunes. The outer margins of the terraces are surrounded by Holocene tidal marshes, bays, and barrier islands. The forest cover is diverse and includes mixed hardwoods, pines, and white cedar swamps. Spartina grasses dominate the marshes.

Across the entire surface of the New Jersey Coastal Plain, periglacial climatic events have left an overprint of abundant colluvial debris underlying low-gradient slopes, deformed surficial strata, and underfit streams. Many low-gradient surfaces are marked by poorly drained, closed depressions. Dune fields of windblown sand are commonly downwind from major valleys. Loess derived from tidal deposits in the lower Delaware River valley is locally abundant.

Northwest of the Fall Line, the Piedmont province consists of low-relief ridges, valleys, and gentle plains underlain by Triassic shale and siltstone of the Newark Supergroup (Owens, Sugarman, Sohl, Parker, and others, 1995; Owens and others, 1998). Higher hills rising from the plains are underlain by 
Jurassic diabase intrusions (Owens, Sugarman, Sohl, Parker, and others, 1995; Owens and others, 1998). The surfaces of these hills are littered with rounded and broken boulders which are the core stones in the residuum weathered from the diabase. Streams draining this portion of the Piedmont, although generally of low gradient and following the strike of bedding or joints in the bedrock, steepen and commonly flow over falls or rapids along the margins of the Delaware River valley. Mature forests include mixed hardwoods; locally, glades of red cedar (juniper) occupy abandoned fields.

\section{SURFICIAL DEPOSITS OF THE COASTAL PLAIN}

\section{NEOGENE FLUVIAL AND MARGINAL-MARINE FORMATIONS}

The Interior Plateaus, Central Uplands, and Southern Uplands of the New Jersey Coastal Plain are underlain by extensive Neogene fluvial and marginal-marine formations. Weathering and erosion of the Neogene formations has produced most of the surficial deposits on the New Jersey Coastal Plain. The distribution of various facies in these formations has controlled the extent, thickness, grain size, and mineralogy of the surficial deposits. The assemblage of these deposits is a surficial aquifer of enormous capacity (Zapecza, 1989). Recharge of the surficial aquifer is rapid and discharge is sustained by a high capacity for long durations. Infiltration into underlying formations also recharges many subsurface aquifers.

The Neogene stratigraphic framework of the New Jersey Coastal Plain includes four exposed surficial formations and one subsurface formation. These units include the Kirkwood (Tkw), Cohansey (Tch, Tchd, Tchg), Bridgeton (Tbr, Tbrg), and Pensauken (Tps) Formations and an unnamed unit (Tu) beneath Cape May Peninsula thought to be equivalent to the Beaverdam Formation (late Pliocene) of eastern Maryland (Owens and Denny, 1978, 1979a,b). These units are all marginal to the Salisbury embayment that underlies the tidewater area of Chesapeake Bay to the south. The Cohansey, Bridgeton, and Pensauken Formations correlate with the marine Miocene formations of the Chesapeake Group (Mixon and others, 1989) that fill the Salisbury embayment. The Pliocene marine deposits (Yorktown Formation) of the Chesapeake Group have not been found in the New Jersey Coastal Plain. During the Pliocene, the New Jersey Coastal Plain apparently was above sea level and subject to prolonged intense weathering and erosion. The Cohansey, Bridgeton, and Pensauken Formations in New Jersey unconformably overlie Cretaceous and Tertiary formations (Owens, Sugarman, Sohl, and Orndorff, 1995; Owens, Sugarman, Sohl, Parker, and others, 1995; Owens and others, 1998). For purposes of subsurface aquifer modeling studies, the Kirkwood in the subcrop has been subdivided into four members based on mineralogy, micropaleontology, and strontium isotopic age dates of mollusks. These units are not readily distinguishable at the surface because of weathering (Owens and others, 1988; Owens, Sugarman, Sohl, and Orndorff, 1995; Owens, Sugarman, Sohl, Parker, and others, 1995; Owens and others, 1998). In earlier classifications, the Kirkwood was divided into the Alloway Clay Member, the Grenloch Sand Member, and the Asbury Clay Member (Isphording and Lodding, 1969). None of these units are directly correlative to the new members of the
Kirkwood (Belleplain Member, Wildwood Member, Shiloh Marl Member, and "unnamed lower member" (Owens and others, 1988; Owens, Sugarman, Sohl, and Orndorff, 1995; Owens, Sugarman, Sohl, Parker, and others, 1995; Owens and others, 1998). The unit formerly described as the Alloway Clay Member (Isphording and Lodding, 1969) occurs in the Salem-Alloway area of southern New Jersey; it is not mapped separately from the Kirkwood.

The Cohansey Formation is a complex siliciclastic assemblage of fluvial-channel (Tchg), deltaic (Tchd), and marginal-marine and shelf deposits (Tch). With the exception of local clay beds, some of which include leafy and woody Miocene peat, the Cohansey is highly permeable and forms a vast recharge area for a shallow ground-water system. Gravel that caps hills adjacent to Raritan Bay was mapped by Lewis and Kümmel (1910-1912) as the Beacon Hill gravel. We consider it to be part of the Cohansey Formation as either isolated remnants of basal fluvial to marine deposits, or as part of the uppermost, last fluvial deposits connected with the upper delta-front deposits of the Cohansey (see also Owens and Minard, 1979). Although marine or estuarine deposits have been observed locally, the gravel facies is dominantly fluvial, occurring along the updip margins of the original depositional basin; some deposits may have been fluvial channel fillings that fed upper delta-front deposits to the south in the Cohansey. The Mullica River valley in southern New Jersey appears to be the northern limit of the extensive upper deltaplain deposits of the Bridgeton Formation. North of the Mullica River valley, a more complete sequence of the Cohansey Formation is preserved underlying hills that exceed $60 \mathrm{~m}$ in altitude. Overlying the lower marine-shelf sequence is $15 \mathrm{~m}$ of intercalated silt to clay beds and sand to gravel beds, sporadically burrowed. Extensive lateral and vertical variations of depositional environments constitute a large delta complex, including lower delta-plain deposits, estuarine deposits, and delta-front deposits. Variations include delta-plain peat (Rachele, 1976) and clay cut by fluvial channels and crevasse splays, intercalated with burrowed marine sand and silt. In the past, these clay horizons have been mined for brick production at Atco, north of Millville at Bricktown in southern New Jersey, and at the abandoned Union Clay Works (located on the map of Lewis and Kümmel, 1910-12) near Woodmansie in central New Jersey. The clay beds pose an unpredictable obstacle for glass-sand dredging operations at many localities where the quartz-rich marine-shelf sands are exploited. The clay to silt interbeds support steeper slopes that rise abruptly above sandy, low-gradient slopes on the marine-shelf facies of the Cohansey Formation. The tops of the hills in this area are covered with a residual cap of bleached quartz and chert pebbles and some insoluble residual clay minerals (residuum at Warrens Grove, OTrw). North of the Mullica River valley in central New Jersey, the marine-shelf sediments (Tch) of the Cohansey are generally covered by Quaternary terraces, sheets of slope deposits, and extensive swamps in valley bottoms.

The Bridgeton (Tbr) and Pensauken (Tps) Formations are arkosic, fluvial deposits that unconformably overlie various facies of the Cohansey Formation in southern New Jersey. In central New Jersey, the Bridgeton and Pensauken also unconformably overlie other Tertiary and Cretaceous formations. The sedimentology of the Bridgeton and Pensauken Formations indicates that they include all the facies typically found in the upper delta plain and channels of a very large, high-discharge river which flowed across southern New Jersey south and 
eastward into the Salisbury embayment (Owens and Minard, 1979). Deposits of the Pensauken are lithically similar to the Bridgeton Formation, but are younger and inset in the Delaware River Valley in southern New Jersey and the Interior Plateaus of central New Jersey at altitudes below the outcrops of the Bridgeton Formation. In southern New Jersey, the Pensauken outcrops are erosional remnants on hills ranging in altitude from 20 to $30 \mathrm{~m}$. In central New Jersey, the Pensauken deposits are confined to an outcrop belt of similar altitudes; the belt is more extensively preserved and conforms well to the array of Pensauken deposits originally mapped by Lewis and Kümmel (1910-1912) and Salisbury and Knapp (1917) for the Geologic Map of New Jersey. Although characteristically arkosic, sediments deposited as alluvial fans and tributary terraces that grade to the main channel are entrenched through all other Coastal Plain units and include deposits locally rich in reworked glauconitic quartz sand and resistant heavy mineral sand. In the South Amboy area, so much excavation and reconstruction of the land surface has occurred that the 1:100,000-scale topographic base map no longer accurately represents the present-day landscape. Contacts at the base of the Pensauken are drawn to reflect the present-day topography shown on the 1:24,000-scale quadrangle maps.

The unnamed unit $(\mathrm{Tu})$ below Cape May Peninsula is known only from examination of cores and borehole geophysics. The unit originally was included in the Cohansey Formation by Gill (1962b). The unit includes a transgressive sequence of marginalmarine sediments that fills a deep channel cut into the Miocene beds. Although the sediments of this unit are physically similar to overlying assemblages of Quaternary marine deposits filling the old Delaware Bay channels, the presence of extinct, exotic flora indicate it is of late Pliocene(?) age (Groot and others, 1990). A cool (fluvial-estuarine) to warm (estuarine-marine) glacial-interglacial climate is suggested by pollen; a basal warm pollen assemblage possibly is reworked. Correlation of this data from the Cape May County Airport corehole with lithic and geophysical logs (see cross section $C-C^{\prime}$ from southern New Jersey) shows how this unit has channeled and truncated late to middle Miocene units, completely removing the middle Miocene Cohansey Formation and part of the middle Miocene Belleplain Member (Owens, Sugarman, Sohl, and Orndorff, 1995; Owens, Sugarman, Sohl, Parker, and others, 1995; Owens and others, 1998) of the Kirkwood Formation from beneath the Cape May Peninsula.

\section{WEATHERED MATERIAL AND TERRESTRIAL DEPOSITS}

Long, subaerial exposure and weathering of the New Jersey Coastal Plain uplands are indicated by pervasive mineral alteration and the migration of clay and silt several meters below the surface. Individual sand grains and other clasts are deeply etched. Less resistant minerals have been altered to clay minerals such as kaolinite and gibbsite (Owens and others, 1983). In the Central Uplands underlain by the Cohansey Formation, erosional remnants are capped by deeply leached, gravel regolith (OTrw) that is the source for abundant, reworked slope deposits of etched, yellow gravel composed of quartz and chert. North of the Cohansey outcrop belt between Freehold and
Red Bank, a distinctive oxidized and limonite-rich regolith (QTrf) caps weathered hills of Tertiary glauconitic sediments.

In a narrow outcrop belt from Salem to Swedesboro, cherty silcrete (Ts) boulders occur on hilltops and in colluvium. The cherty clasts are remnants of a silica-cemented soil horizon. Silcrete is not forming in New Jersey today; the presence and proximity of silcrete to erosional remnants of the Pensauken Formation suggest that it formed in a warm, wet climate during the late Miocene and Pliocene (Wyckoff and Newell, 1992). Large chert boulders noted by Minard (1965) in the surficial deposits of the Woodstown area probably are the same material. Silcrete clasts have been observed as far up the Delaware River Valley as the hills south of Mantua Creek in southern New Jersey. Silica-cemented Cohansey deposits have been recognized on the tops of hills in the Roosevelt quadrangle (Minard, 1964) in central New Jersey. Slab-shaped boulders of silica-cemented, molluskbearing quartzite have been found at Fairton at the mouth of Mill Creek at the head of tide on Cohansey Creek in southern New Jersey. The boulders were dredged from the subsurface during development of the navigation channel to Fairton; the exact stratigraphic position of the quartzite is uncertain. Although called "Cohansey Quartzite" (Richards and Harbison, 1942), it may be correlative with shell beds in the Kirkwood Formation at Marlboro (L.W. Ward, written commun., 1986). Locally, in prehistoric times, this material was used for projectile points. More recently, it has been used for building stone in nearby Bridgeton.

Most of the terrestrial surficial deposits of the New Jersey Coastal Plain are colluvium and alluvium derived from the weathered Bridgeton and Cohansey Formations during erosion of the uplands (units $\mathrm{Qca}_{5}$ through $\mathrm{Oca}_{1}$ ). Examination of numerous exposures indicates a widely distributed array of surficial deposits that are poorly sorted, include matrix-supported clasts, and underlie alluvial fans, debris flows, and sequences of graded terraces. The colluvial deposits are commonly less than $3 \mathrm{~m}$ thick and unconformably overlie Tertiary sediments. Although these deposits are thin, they are ubiquitous, polycyclic, and locally can be mapped as sequences of erosional and depositional events with crosscutting relationships. Slope deposits ( $\mathrm{OCa}_{2}$ and older) commonly have eroded margins and occur as erosional remnants above adjacent surfaces underlain by $\mathrm{Qca}_{1}$ deposits. Erosional remnants capped by $\mathbf{Q c a}_{4}$ and $\mathbf{Q c a}_{5}$ slope deposits occur as high benches, pinnacles, or ridges along major watershed divides. These deposits are the earliest preserved remnants of denudation of the landscape and may be pre-Quaternary at some localities.

In the mid-Atlantic region, there are no modern analogues to the surficial deposits that are as extensive as those shown on the maps. During warm, humid, interglacial periods, the surface aquifer is rapidly recharged. Surface runoff is minimal and surficial processes have little effect in eroding and redistributing sediment on the landscape. These conditions were repeated during earlier interglacial periods.

Frozen ground phenomena, such as frost wedges and congeliturbated deposits (McRoberts and Morgenstern, 1974; French, 1976; Washburn, 1980; Carter and others, 1987; Newell and others, 1989), have been observed across the New Jersey Coastal Plain in numerous excavations. These features indicate that a periglacial climate prevailed during possibly several continental glacial advances across northern New Jersey (see Stone and others, 1995, in press). Seasonal melting created a saturated thaw zone at the surface overlying an impermeable 
frozen substrate. Additional precipitation from summer storms mobilized the saturated zone; widespread erosion and deposition of surficial deposits occurred after the threshold for slope stability was exceeded (Newell and Wyckoff, 1992).

Exposures of colluvium are commonly devoid of any dateable organic remains. The deposits have been leached, weathered, locally eroded, and overlain by windblown materials. Each valley has its own sequence of deposits. Along the Coastal Lowlands, colluvium has been deposited unconformably on the tops of marine terraces. Although a hierarchy of colluvial deposits can be defined, age control is lacking. All slopes and level surfaces were modified to some extent during the last glacial event.

The youngest colluvial-alluvial deposits $\left(\mathrm{Oca}_{1 \mathrm{~b}}\right)$ are mapped only in the headwaters of the Mullica River in southern New Jersey. The surface of these deposits is engraved with a pattern of braided stream channels. Exposures reveal bedforms and sorting that can only be deposited by stream discharges that were orders of magnitude beyond the scale of the largest modern runoff events. The braided-channel surfaces are devoid of frozen ground features as are other postglacial Holocene deposits. Thus, this deposit is interpreted as the product of extreme discharge from large storms combined with meltwater from the final thaw of permafrost (Newell and Wyckoff, 1992). Following permafrost melt and discharge, the surficial aquifer system was reestablished and contributed ground-water discharge directly to streams. Holocene stream channels and flood plains are characteristically underfit within broad Pleistocene valleys.

\section{Lithology of Colluvial Slope Deposits}

Colluvial deposits on slopes are derived from underlying materials and from other nearby sources. Over most of the Central and Southern Uplands, the Bridgeton and Cohansey Formations are the sources for most of the colluvium. Along the lower reaches of valleys in the Interior Plateaus, extensive quartzrich colluvium from the Cohansey Formation overlies the outcrop belt of Cretaceous and Paleogene stratigraphic units (Owens, Sugarman, Sohl, and Orndorff, 1995; Owens, Sugarman, Sohl, Parker, and others, 1995; Owens and others, 1998). Locally, colluvium derived from greensand (glauconite) is also distinctive.

Considerable colluvium generated from weathered Bridgeton deposits overlies the Cohansey Formation along the western edge of the Southern Uplands and also within local river valleys incised through the Bridgeton into the Cohansey Formation. At these localities, slopes on the Bridgeton Formation are generally steeper than slopes eroded in the Cohansey Formation. The colluvium is usually thickest under the break in slope between the two formations.

Locally, clay mineralogy studied in profiles of the colluvium indicates a series of eroded and redeposited sediments. Sequences of slope deposits have differing depths of weathering and soil development and display a consistent pattern of claymineral authigenesis and degradation. Typically, weathered colluvium includes vermiculite, illite, kaolinite, gibbsite, goethite, clay-size quartz, and lepidocrocite; illite and kaolinite increase with depth. Lepidocrocite is present within the deeper portions of the weathering profile and is considered to be an early pedogenic product at the incipient margin of weathering. Claysize quartz is usually more abundant at depth and may indicate the illuviation of fine material from overlying windblown deposits, or it may accumulate in place from the degradation of the surface of the quartz grains. Vermiculite content decreases with depth and is more abundant at the surface.

At some localities, colluvium derived from the Bridgeton Formation presents an inverted organization of the typical suite of clay minerals. Generally, the deeply weathered Bridgeton Formation (Owens and others, 1983) contains a sequence of clay minerals that, when eroded and redeposited (as in colluvium), commonly produces a "clay stratigraphy" that inversely repeats the sequence that developed in place.

Colluvium derived from the Bridgeton Formation includes all the lithic affinities and particle-size range of the parent material. The colluvium contains less feldspar than the parent materials and almost all of the feldspar that remains is orthoclase. The lithic diversity of gravel within the colluvium is less than the lithic diversity within the Bridgeton; the gravel contains mostly quartz and chert clasts, although Paleozoic and Mesozoic sandstone clasts locally are preserved.

The various facies of the Cohansey Formation are the most extensive sources of surficial deposits shown on the maps. However, some slope deposits in central New Jersey are derived from the outcrops of Cretaceous and Tertiary strata. All the major tributary valleys to the tidal Delaware River and the Raritan Bay cut down through the stratigraphic section and across the strike of most units. Thus, surficial deposits in these valleys are an aggregate of sediments stripped and mixed from the various formations. Those derived from the Pensauken and Bridgeton Formations are rich in reworked arkosic sediments and distinctive suites of clay minerals (as described above). Owens and Minard (1975) distinguished surficial deposits largely by lithology (arkosic, quartz-rich, or greensand-rich), unconformities, and transecting patterns of erosion and deposition. Quartzose colluvium is derived primarily from the Cohansey Formation and includes dominantly quartz sand and pebbles with lesser amounts of resistant heavy minerals and chert. Greensand colluvium is distinguished by abundant reworked glauconite derived from stripping of Cretaceous and Tertiary greensand-rich formations. Slope and stream processes that have moved and sorted glauconite and quartz sand have created alternating laminated beds of the two components that are sometimes disrupted by burrows or root casts. Glauconitic surficial deposits also occur where windblown dune fields have originated in the glauconitic colluvium and have been blown back onto low ridges from valley bottoms and lower slopes.

\section{Morphostratigraphy of Colluvial Slope Deposits}

A slope-deposit map unit (colluvium and alluvium, units $\mathrm{Oca}_{1}$, $\mathrm{Oca}_{2}$, and $\mathrm{Oca}_{3}$ ) overlaps each set of Cape May Formation terrace deposits $\left(\mathrm{Ocm}_{1}, \mathrm{Qcm}_{2}\right.$, and $\left.\mathrm{Qcm}_{3}\right)$. The juxtaposed and overlapping marine and terrestrial deposits represent complete cycles of warm climate to cold climate processes. As shown in the Correlation of Map Units and in the Description of Map Units, warm climates are indicated by the sea-level high stands of the Cape May Formation and cold climates are interpreted from extensive stripping, deposition in valley bottoms, and numerous relict features of frozen ground. Evidence of active slope processes on the New Jersey Coastal Plain during warm interglacial periods is not apparent. In southern New Jersey, parent materials for surficial deposits are uniform and extensive (Bridgeton and Cohansey Formations); the sequential array of slope deposits in the various evolving watersheds can be crudely timed with the intervening high stands represented by the units 
of the Cape May Formation (see Correlation of Map Units). In central New Jersey, the evidence for this correlation is less clear. All ${ }^{14} \mathrm{C}$ dates are from the end of the last glacial event and are generally Holocene.

A four-fold sequence of slope deposits $\left(\mathrm{Oca}_{1}\right.$ through $\left.\mathrm{Qca}_{4}\right)$ can be superimposed on most of the eroded landscapes in the Central Uplands of the New Jersey Coastal Plain. In southern New Jersey in the headwaters of the Salem River and Alloway Creek, an area of complex drainage evolution and scarp retreat, a sequence of five discrete slope deposits has been mapped. Whether the sequences of deposits in different watersheds all represent the same climatic events cannot be determined; these deposits cannot be correlated accurately and uniformly across the landscape. Some of the oldest, highest deposits that are prominent erosional remnants are possibly as old as the Pensauken fluvial deposits. Old erosional remnants of colluvium have been thoroughly leached and oxidized and have been extensively modified by later mass-wasting events. At some localities where old surficial deposits were originally thin and rested upon impermeable materials, all that remains are a few scattered pebbles. The substrate in headward-eroding watersheds also controls the areal distribution and extent of the surficial deposits. For example, areas underlain by cohesive matrix sediments or by clay interbeds may be characterized by numerous small-scale alluvial fans, debris flows, and thin, continuous colluvium. Areas underlain by well-sorted, easily eroded sand may be characterized by thick, extensive surficial deposits.

In central New Jersey, surficial deposits, especially slope deposits, are derived from many different lithologies (Owens, Sugarman, Sohl, Parker, and others, 1995; Owens and others, 1998). The watersheds and tributaries developed in differing assemblages of Coastal Plain strata and present a complex history of drainage-basin evolution. Thus, the classification we are presenting of slope deposits in a four-fold hierarchy captures their position on the landscape but does not imply wide regional correlation of events and deposits. As shown in figure 4, Qca, represents the youngest deposits in valley bottoms and slopes of ravines. $\mathrm{Qca}_{2}$ represents isolated benches of slope deposits which have been disconnected from areas of active erosion and deposition within headward-eroding valleys. $\mathrm{Oca}_{3}$ represents extensive weathered, erosional remnants which cap low divides between a group of small first- and second-order watersheds. $\mathrm{Oca}_{4}$ (and $\mathrm{Oca}_{5}$ in southern New Jersey) represent the highest erosional remnants; they cap major divides on the landscape, but also are subordinate to source areas of higher altitude. (Along the lower Delaware River valley and adjacent to Delaware Bay, some intermediate uplands are capped with fluvial-colluvial gravel complexes that are deeply weathered and dissected (OTcau). These deposits may have affinities for the early topographic evolution of the Pensauken valley.) The lowest, most extensive deposits are also the youngest and are broadly coeval. Correlation from place to place of older, higher, more limited deposits is less certain. The very youngest slope deposits $\left(\mathrm{Oca}_{1 \mathrm{~b}}\right.$ and $\mathbf{Q c a}_{1 \mathrm{~d}}$ ) as mapped in southern New Jersey are unique because they are neither homogenized nor congeliturbated by freezing and thawing.

\section{QUATERNARY MARINE, ESTUARINE, AND ASSOCIATED FLUVIAL DEPOSITS}

Early reports of surficial deposits in the New Jersey Coastal Plain described the Bridgeton Formation and Pensauken Formation as Pleistocene glacial outwash (Salisbury and Knapp, 1917). The Pleistocene Cape May Formation was mapped as uplifted marine deposits on coast-facing terraces at a uniform altitude (less than $15 \mathrm{~m}$ ). Numerous deposits now recognized as Pleistocene and Holocene alluvium and colluvium were included in the Cape May Formation because of their similar altitudes without regard to lithology, bedding, unconformities, geomorphology, fauna, flora, and other distinctive characteristics. Salisbury's map of the Trenton area (in Bascom, Clark, and others, 1909) included glacial outwash and other surficial deposits in the Cape May Formation. The Geologic Map of New Jersey that followed (Lewis and Kümmel, 1910-1912) separated "stratified drift" from the Cape May Formation in the Trenton area.

Regional geologic mapping and subsurface work in the middle Atlantic States (Owens and Minard, 1979) demonstrate that the Bridgeton and Pensauken Formations are correlative with Miocene marine formations in the Salisbury embayment of Maryland. Several lithic phases of the Bridgeton, Pensauken, and Cape May were formerly defined and mapped by Salisbury and Knapp (1917) based largely on commonality of altitudes. The deposits included in these phases are now recognized as colluvium and alluvium.

Detailed examination of petrography, sedimentology, geomorphology, paleontology, weathering studies, and various dating techniques have contributed to a redefinition of the original Cape May Formation. As now mapped, the Cape May Formation includes at least three transgressive-regressive sequences which correlate well with established Quaternary marine stratigraphy in the Chesapeake Bay and with nearby Atlantic Coast stratigraphy (Mixon and others, 1982, 1989; Mixon, 1985). The transgressive-regressive sequences are mapped as unit $1\left(\mathrm{Qcm}_{1}\right.$, no younger than 30 to $\left.28 \mathrm{ka}\right)$, unit 2 $\left(0 \mathrm{~cm}_{2}, 71 \pm 7 \mathrm{ka}\right)$, and unit $3\left(\mathrm{Ccm}_{3}, 184 \pm 20 \mathrm{ka}\right)$. In some areas, extensive residential and commercial development, poor exposure, and poor topographic control make it difficult to distinguish these units. Each transgressive-regressive sequence has allostratigraphic facies equivalents along the Delaware River estuary from Delaware Bay to the Fall Line. In the Trenton area at the Fall Line, two fluvial gravel deposits were mapped by Minard and Rhodehammel (1969) and Owens and Minard (1975, 1979), first as Quaternary arkose 1 and Quaternary arkose 2 and later informally as the Van Sciver Lake beds (Ovl) and the Spring Lake beds (OsI). These materials, first presented as stratified drift or outwash by Salisbury (1902), Salisbury (in Bascom, Clark, and others, 1909), and Salisbury and Knapp (1917), were interpreted by Owens and Minard (1979) as mostly fluvial facies of the Cape May sequences. Recent mapping for this report indicates that these deposits are more complex in their provenance and history. The Van Sciver Lake and Spring Lake beds may correlate with the Cape May Formation; however, there is not enough evidence to include them as part of the Cape May. 
Each transgressive-regressive sequence of the Cape May Formation is marked by a deep valley cut through older Coastal Plain strata that is filled with boulders and gravel that may represent cold climate outwash transported from the upper Delaware River valley. The boulders and gravel include a wide array of rock types from northern New Jersey and beyond. The fluvial deposits locally include fresh-water peat and are overlain by fine-grained sediments which include brackish-water fauna near the base (Rangia, sp.) and full-marine-salinity fauna at the top (Mercenaria, sp.). Pollen spectra through each sequence generally show progressive warming trends (Sirkin and others, 1970). The top of each sequence marks the sea-level high stand and records climate cooling and sea-level lowering. The morphology of each terrace surface commonly reveals old bars, spits, and inlets.

From the evidence in New Jersey, it is uncertain whether or not every sea-level rise reached the same altitude. Generally, the oldest deposits are the highest and deposits from younger events are inset below them, possibly indicating a long-term uplift. Although younger transgressions locally have stripped off evidence of older sea-level high stands, buried valleys filled with the marine facies of earlier events are commonly encountered when drilling through unit 1 and unit 2 terrace deposits of the Cape May Formation. Relative dating techniques, such as amino-acid racemization in mollusks (Groot and others, 1990), yield clustered dates from these buried deposits that generally support a stratigraphic and geomorphic interpretation of two or three transgressive events.

\section{PLEISTOCENE AND HOLOCENE DEPOSITS}

Holocene deposits on the Central and Southern Uplands and Interior Plateaus of the New Jersey Coastal Plain are minimal. Most of the area is covered with permeable materials that have limited runoff, erosion, and deposition. Major stream-valley bottoms contain limited flood-plain deposits ( $\mathrm{Oa}$ ) which are inset below the older surficial deposits left by cold-climate processes. Most Holocene sedimentation is an ongoing process that occurs at the marine margin. As sea level rises, barrier islands ( $\mathrm{Ob}$ ) migrate landward and bays and lagoons that have formed behind them are filled with landward-transported sediment and peat. Along the marine margin, salt-marsh peat $(\mathrm{Om})$ accumulates on top of fresh-water swamp deposits (Os). Northward along the New Jersey shore, Holocene marginal-marine deposits are juxtaposed against sequentially older Quaternary, Tertiary, and Cretaceous strata.

Coastal erosion has been documented from the earliest colonial occupation. Aside from the transient nature of the barrier islands, the most extensive loss of land has occurred around Delaware Bay from Cape May to the Maurice River.

Holocene windblown sand and very fine gravel mapped as part of $\mathrm{Ob}$ is most evident along the barrier-island beaches and along the Delaware Bay shoreline of the Cape May Peninsula. These deposits are yellow, white, brown, and gray; they include wellrounded, frosted grains of quartz, chert, and heavy minerals in massive to poorly bedded sheets and dunes that blanket flood plains, terraces, and valley-wall intersections, as well as pre- existing surficial and bedrock units. The thickest deposits $(3 \mathrm{~m})$ occur as downwind shadows along major valleys and terraces. The major sources for the sediment are Delaware River valley terraces and flood plains of major rivers. A layer of windpolished and wind-faceted pebbles and cobbles is common on surfaces below the deposits.

Pleistocene and Holocene loess deposits overlie some map units in the west-central part of the State (fig. 3). Loess deposits on the uplands, east of Salem and Woodstown, originate from a particularly silty region on the estuarine terraces along nearby Delaware Bay. Loess consists of silt, very fine sand, and clay. The silt and sand is quartz rich with a broad range of resistant to easily weathered minerals. Deposits cover pre-existing units with a 0.1 - to 1.5-m-thick cap of gray to buff, columnar-jointed sediments blown out of the Delaware River valley terraces and across upland scarps. A layer of wind-polished and wind-faceted pebbles and cobbles is common on surfaces below the loess.

Locally, where agriculture and forest fires have stripped the land of cover, Pleistocene dune fields $(\mathrm{Qe})$ have been reactivated. These dunes contain windblown sand derived from Mesozoic and Cenozoic formations and from Quaternary estuarine terraces. They are most active in areas of extensive tillage and along active shorelines. Only the thickest sand dunes and extensive sheets of windblown sand are shown on the maps.

\section{MANMADE DEPOSITS}

From the colonial era to the present, the extraction of mineral resources and the construction of engineering works have left a distinctive topographic signature of excavated pits and deposits of reworked materials that cover many square miles. They reflect changing technologies and regulations for the extraction of materials and the casting off of overburden, tailings (amt, amg), and dredge spoil (ds). In the Piedmont, diabase is quarried for road metal and aggregate; the quarries and tailings are mapped as unit amd. Compacted and graded industrial sites, waste storage facilities, and fill for transportation ramps and causeways are additional kinds of manmade deposits (af). During Colonial times, tidal marshes along the Delaware Bay and major tributaries, including the Salem, Cohansey, and Maurice Rivers, were diked and farmed as "polders" as had been done in the Netherlands and East Anglia, Great Britain. These works have fallen into disrepair for over 150 years and have not been mapped. Many interior watersheds, including the headwaters of the Mullica River, Toms River, Rancocas Creek, and others, have been extensively modified to create dikes, bogs (cb), and reservoirs for the cultivation of cranberries.

\section{SURFICIAL DEPOSITS OF THE PIEDMONT}

Northwest of the Coastal Plain (fig. 2), the Piedmont landscape is characterized by low-relief hills and broad valleys underlain by the Triassic continental sediments of the Newark basin (Owens, Sugarman, Sohl, Parker, and others, 1995; Owens and others, 1998). Higher, broader hills are underlain by Jurassic diabase dikes and sills which intrude the sandstones and shales. Diabase has been quarried and used for road metal and aggregate. Surficial deposits on this landscape include residuum, colluvium, 
alluvium, and windblown sand and silt. Colluvial deposits (Qcs, Ocd, Qcb, Qcal, and Qdrh), which accumulated on hillslopes, are divided on the basis of lithologic characteristics related to upslope bedrock units from which they have been derived. Residual materials (Osw, QTdw, and QTbw) derived from weathering of bedrock are distinguished by grain size, structure, and mineral composition. Residual products include saprolite, grus, and rock rubble.

Fluvial deposits (Qa, Qdi, Oml, Qst, Qalb, Qf, and Qstu) underlie modern flood plains and stream terraces, and are differentiated on the basis of grain size, weathering characteristics, stratigraphic relationships, and topographic position. Windblown sand and silt deposits $(\mathrm{Qe})$ are shown where they are greater than $1 \mathrm{~m}$ thick. Eolian silt to fine sand is mixed within the surface soil horizons throughout the area.

Deposits of glacial origin (Ordl, Olbr, and Qps) are subdivided on the basis of grain size, provenance, and age. Glacial deposits are related to three glaciations of New Jersey, from youngest to oldest: late Wisconsinan (Qrdl), Illinoian (Qlbr), and pre-Illinoian (Ops). Although no glacial terminus reached as far south as the map area, meltwater deposits of sand, gravel, cobbles, and boulders originated from the continental glaciers to the north. They occur as thick, braided, outwash-channel deposits underlying high terraces along the valleys of through-flowing rivers including the Delaware, Raritan, and (possibly) the Millstone Rivers. The deposits continue below sea level along the submerged channel of each river, far out on the continental shelf (Knebel and Circé, 1988).

\section{GEOLOGIC MAPPING AND THE ECONOMIC DEVELOPMENT OF THE NEW JERSEY COASTAL PLAIN}

The exploitation of the natural resources of the New Jersey Coastal Plain can be characterized by three periods, each of which sustained several economic cycles, changing demographics, politics, and land-use mandates. The three periods are the colonial era, the Industrial Revolution, and the post-industrial era. Figure 5 schematically shows the history of resource exploitation on the New Jersey Coastal Plain through these three eras. Economic thresholds from time to time stimulated public investment in geologic mapping as a "public good." The demand for new information has accompanied each transition from one economic era to another.

The New Jersey Coastal Plain was first settled by the Swedes and the Dutch early in the seventeenth century. Later in the seventeenth century, New Jersey was established as an English colony under two proprietors (Lords Carteret and Berkeley). Following initial colonization, a period of agrarian activity was sustained for two centuries. Areas of naturally fertile, easily cultivated soil close to local markets were the first to be farmed. Plantations producing single-commodity cash crops for export were not generally established. Almost from the first, the resources of New Jersey supported the growth and sustenance of two urban areas, New York and Philadelphia; the intervening low-relief terrain along the Fall Line became an important transportation corridor. Early efforts at manufacturing iron and glass were initiated in the first half of the eighteenth century.
Both activities relied entirely on the use of native materials. Iron was smelted from limonite that had precipitated from ground water in the bottoms of streams, swamps, and "spungs" (upland bogs). Crushed oyster and clam shells were an effective flux. Charcoal made in the surrounding forests fueled furnaces that were located along creeks. The creeks were dammed and water power drove the bellows that provided a blast of air to the conflagration. Local sand was used on the molding floor. Similarly, glass was made and blown using quartz-rich sand from dune fields and other surficial deposits derived from the Cohansey Formation; charcoal was the earliest fuel. The colonial iron industry required vast land holdings and a community of dedicated labor and support similar to plantation agriculture. The "bog ore" furnaces of the Pine Barrens provided munitions for the American Revolution and armaments for the early ships of the U.S. Navy. Although some furnaces maintained production into the mid-nineteenth century, all were obsolete at the beginning of the Industrial Revolution. Superior resources of ore, limestone, and coal to the north and west were used to outproduce the crude colonial furnaces and to support the new technology of steel production.

By contrast, the glass sand resources of the Cohansey Formation in the New Jersey Coastal Plain proved to be of such quality and abundance that fuel and labor were brought to the source; the mining of glass sand and production of glass remain an important part of the economy in southern New Jersey.

During the colonial period, bricks were made extensively using clay-rich soils near sites of construction. Early pottery was made from the abundant Cretaceous clay exposed in many river banks.

The advent of the Industrial Revolution in New Jersey can be marked by two events: the development and use of steam engines and the beginnings of concentrated manufacturing north of the Coastal Plain at Paterson and also at Trenton and New Brunswick along the Fall Line. The development of industrial manufacturing centers brought together a variety of mills, foundries, forges, brick yards, and potteries that not only exploited abundant water power, but also required transportation for raw materials and products. Canals met this need but were superseded by steam-powered railroads that proliferated before and after the Civil War.

As the Industrial Revolution unfolded, the assessment and documentation of natural resources became more comprehensive and sophisticated as the needs for information became increasingly complex. The earliest accounts were, at best anecdotal, entrepreneurial, and prone to exaggeration. The Industrial Revolution required unbiased, factual information leading to early geological surveys of the mid-Atlantic States. The New Jersey State legislature of 1835 authorized a geological survey to be accomplished by Professor Henry D. Rogers of the University of Pennsylvania. The work was reconnaissance in nature and eventually inspired another more extended survey which was authorized in 1854 . The scope of the work might be characterized as an inventory of resources for industry and agriculture. The work was set back by a loss of financial support before and during the Civil War. The value of the information was so compelling that the first two State Geologists, William Kitchell and George Cook, solicited and received support from the State Agricultural Society for the completion of a geologic map. Following completion of the geologic map, annual funds were forthcoming from the State legislature for continued investigations of various natural resources. Cook recognized the need for an accurate statewide topographic map and was 
successful in implementing a topographic survey. The resulting topographic maps of New Jersey became the centerpiece of an atlas of geographic information and remained in general use until superseded by U.S. Geological Survey 7.5-minute quadrangle maps after World War II.

During the nineteenth century, American agricultural productivity increased through the use of phosphate fertilizers. On the New Jersey Coastal Plain, the extensive Cretaceous and Tertiary glauconite beds (greensands, marls, shelly marls, and derivative surficial deposits) were recognized as a superior and abundant phosphate source. The development of a railroad network made the marls widely available and their use dramatically increased the productivity and value of New Jersey farmland.

Excavation of gravels for constructing road beds (rail and wagon) and for concrete aggregate accelerated as the transportation network developed. The first part of the Industrial Revolution in New Jersey was essentially internal. Native resources were transported, manufactured, and used locally within the State as well as in the Philadelphia and New York markets. The middle of the Industrial Revolution was characterized by the exportation of enormous quantities of goods manufactured from native resources, including glass, bricks, ceramics, sand, and gravel for the building of the urban infrastructure up and down the mid-Atlantic Coast. The expanding agricultural production and advent of food-processing technology stimulated the growth of the New Jersey glass industry as new forms of packaging and shipping of foods were developed. This synergy was repeated many times as electrification, architecture, and transportation all created new demands for materials.

The development of steam power and eventually electricity eliminated the need for manufacturing to be located adjacent to falls, dams, and canals for water power. Consequently, water resources began to be appreciated for their abundance, quality, and need for sustaining urban populations. Vast tracts in the Coastal Plain interior (the Pine Barrens) were purchased and held as a reserve. Cranberry agriculture also superseded many of the old watersheds formerly used for iron and glass production. Both the new agriculture and the new urban society recognized the need for watershed protection and management.

The latter decades of the nineteenth century and the early decades of the twentieth century were times of great advances in the application of the scientific method to medicine, engineering, public health, and all aspects of technological growth. Although resources in the Western States may have seemed abundant beyond measure, in the old, small Eastern States, the finite limitations of nearby resources were understood. As the State's population swelled, an embryonic sense of a conservation ethic focused on watershed protection, European-style silvaculture, and stewardship of renewable resources.

At the end of Cook's long career, in the middle 1880's, new geologic mapping was initiated based on the new topographic map produced by the New Jersey Geological Survey. Simultaneously, new geologic mapping by the U.S. Geological Survey was presented in comprehensive reports of urban areas surrounding Newark, Trenton, and Philadelphia as a new folio map series, The Geologic Atlas of the United States. These folio maps, the Geologic Map of New Jersey, and associated reports were more than an inventory; they interpreted geologic history and processes as understood at the beginning of the twentieth century. In this century, geologic investigations have been largely applied to assessing water resources and developing modeling techniques that define flow paths in aquifers.

The geologic research and mapping of resources mandated by the Industrial Revolution at the beginning of the twentieth century were so successful that the State legislature proceeded under the impression that the job was done; all that remained for future generations was to update and use the information at hand. The last chapters of the Final Report (by Salisbury and Knapp, 1917) had been achieved on the eve of our entry into World War I.

The last part of the Industrial Revolution in New Jersey used the transportation network, existing industrial sites, and the skilled labor force to process imported raw materials using imported energy resources (coal, oil and gas). Shortly after World War I, the U.S. Army Corps of Engineers initiated coastalerosion protection projects and dredging of navigation channels on the Delaware and Raritan Rivers, which facilitated larger scale shipping along those routes.

Glass sand and glass ware, brickmaking, and ceramics continued in importance well after World War II. The last prospecting for new mineral resources in the New Jersey Coastal Plain occurred after World War II. A few seismic-reflection profiles and deep drill holes revealed a lack of potential for hydrocarbons. Titanium-rich sands were located and mined from the Cohansey Formation near Lakehurst. Eventually, the cost of production and the value of the land overshadowed the value of the mineral resources. Additional mapping initiatives focused on reinterpreting geology in order to understand and assess mineral and water resources.

The post-industrial era in New Jersey has been characterized by a proliferation of research parks, corporate headquarters, and warehousing and shipping centers. The study of natural resources of the Coastal Plain is now focused on sustaining the water resources for an expanding population. Heavy industry is being replaced by research, development, and service enterprises. Safe storage for waste is being regionalized and engineered and Environmental Protection Agency Superfund sites are targeted for containment and remediation. This present focus requires an understanding of the geologic framework in order to identify construction materials, select sites, and protect watersheds and aquifers. Sand and gravel for aggregate, clay for impermeable liners and covers, and abundant, clean water have become compelling needs that must be met as urbanization relentlessly diminishes areas traditionally used for agriculture, mining, and forestry.

New housing and recreation areas now commonly replace old pits and industrial sites, often becoming the last of an unfolding pattern of sequential land use. Many former clay pits along Raritan Bay have been used for sanitary landfills or have been graded for apartment complexes, condominiums, and housing developments. Old sand pits that have been regraded and allowed to fill with ground water have been transformed from raw abandoned areas into recreational lakes that have become focal points of suburban community landscapes.

The latest statewide initiative for geologic mapping of New Jersey, which began in 1984, was funded as a cooperative effort between the New Jersey Geological Survey and the U.S. Geological Survey. The new geologic maps contain information valuable for assessing aquifers, protecting ground-water recharge areas, assessing water quality, and providing a framework for evaluating hazards and resources for rebuilding the urban infrastructure. The maps present information that is not only relevant for the inventory of resources and the interpretation of 
geologic history, but also facilitates an understanding of the magnitude and frequency of Earth's surface processes and the natural systems that sustain them.

The trend of present and future resource needs from the New Jersey Coastal Plain requires the presentation of traditional information in new formats (digital spatial-data sets). These data, commonly as a digital geographic information system, can be analyzed with other spatial-data sets for new assessments and decisions.

\section{REFERENCES CITED}

Bascom, F., Clark, W.B., Darton, N.H., Kümmel, H.B., Salisbury, R.D., Miller, B.L., and Knapp, G.N., 1909, Description of the Philadelphia district [Norristown, Germantown, Chester, and Philadelphia quadrangles, Pennsylvania-New Jersey-Delaware]: U.S. Geological Survey, Geologic Atlas, Folio 162, 24 p., 10 map sheets, scale 1:125,000.

Bascom, F., Darton, N.H., Kümmel, H.B., Clark, W.B., Miller, B.L., and Salisbury, R.D., 1909, Description of the Trenton quadrangle, New Jersey-Pennsylvania: U.S. Geological Survey, Geologic Atlas, Folio 167, 24 p., 3 map sheets, scale 1:125,000.

Bayley, W.S., Kümmel, H.B., and Salisbury, R.D., 1914, Description of the Raritan quadrangle, New Jersey: U.S. Geological Survey, Geologic Atlas, Folio 191, 32 p., 5 map sheets, scale 1:125,000.

Berger, Jonathan, and Sinton, J.W., 1985, Water, earth, and fire-Land use and environmental planning in the New Jersey Pine Barrens: Baltimore, Md., Johns Hopkins University Press, 228 p.

Carter, L.D., Heginbottom, J.A., Woo, Ming-ko, 1987, Arctic lowlands, chapter 14 in Graf, W.L., ed., Geomorphic systems of North America: Boulder, Colo., Geological Society of America Centennial Special Volume 2, p. 583-628.

Farrell, S.C., Gagnon, Keith, Malinousky, Thomas, Colombo, Robert, Mujica, Karen, Mitrocsak, Janet, Cozzi, Andrew, Van Woudenberg, Edward, and Weisbecker, Thomas, 1983, Pleistocene? braided stream deposits in the Atsion quadrangle area, northwestern Atlantic County, New Jersey, in Talkington, R.W., ed., Geological investigations of the coastal plain of southern New Jersey, part 1, field guide: New Brunswick, N.J., New Jersey Geological Society, p. A1-A12.

French, H.M., 1976, The periglacial environment: London, Longman Group Limited, 309 p.

Gill, H.E., 1959, Geology and ground-water resources of the Cape May Peninsula, lower Cape May County, New Jersey: New Jersey Department of Conservation and Economic Development Water Resources Circular 1, 19 p.

-1962a, Ground-water resources of Cape May County, New Jersey-Saltwater invasion of principal aquifers: New Jersey Department of Conservation and Economic Development, Division of Water Policy and Supply, Special Report 18, 171 p.

-1962b, Records of wells, well logs and stratigraphy of Cape May County, New Jersey: New Jersey Department of Conservation and Economic Development, Division of Water Policy and Supply, Water Resources Circular 8, 54 p.
Groot, J.J., 1991, Palynological evidence for late Miocene, Pliocene and early Pleistocene climatic changes in the middle U.S. Atlantic Coastal Plain: Quaternary Science Reviews, v. 10, p. 147-162.

Groot, J.J., Ramsey, K.W., and Wehmiller, J.F., 1990, Ages of the Bethany, Beaverdam, and Omar formations of southern Delaware: Delaware Geological Survey Report of Investigations 47, $19 \mathrm{p}$.

Horton, J.W., Jr., Drake, A.A., Jr., and Rankin, D.W., 1989, Tectonostratigraphic terranes and their Paleozoic boundaries in the central and southern Appalachians, in Dallmeyer, R.D., ed., Terranes in the Circum-Atlantic Paleozoic orogens: Geological Society of America Special Paper 230, p. 213-245.

Horton, J.W., Jr., Drake, A.A., Jr., Rankin, D.W., and Dallmeyer, R.D., 1991, Preliminary tectonostratigraphic terrane map of the central and southern Appalachians: U.S. Geological Survey Miscellaneous Investigations Series Map I-2163, scale 1:2,000,000.

Isphording, W.C., and Lodding, William, 1969, Facies changes in sediments of Miocene age in New Jersey, in Subitzky, Seymour, ed., Geology of selected areas in New Jersey and eastern Pennsylvania and guidebook of excursions: New Brunswick., N.J., Rutgers University Press, p. 7-13.

Knebel, H.J., 1992, Late Pleistocene and Holocene development of Delaware Bay, in Gohn, G.S., ed., Proceedings of the 1988 U.S. Geological Survey workshop on the geology and geohydrology of the Atlantic Coastal Plain: U.S. Geological Survey Circular 1059, p. 61-63.

Knebel, H.J., and Circé, R.C., 1988, Late Pleistocene drainage systems beneath Delaware Bay: Marine Geology, v. 78, no. 3-4, p. 285-302.

Krynine, P.D., 1948, The megascopic study and field classification of sedimentary rocks: Journal of Geology, v. 56 , no. 2, p. 130-165.

Lewis, J.V., and Kümmel, H.B., 1910-1912, Geologic map of New Jersey: Trenton, N.J., New Jersey Geological Survey, scale 1:250,000. [Revised by H.B. Kümmel in 1931 and by M.E. Johnson in 1950 and issued by New Jersey Department of Conservation and Economic Development as Atlas Sheet 40.]

Martino, R.L., 1981, The sedimentology of the late Tertiary Bridgeton and Pensauken Formations in southern New Jersey: New Brunswick, N.J., Rutgers University, unpublished Ph.D. dissertation, 283 p.

MacClintock, Paul, 1940, Weathering of the Jerseyan till: Geological Society of America Bulletin, v. 51, no. 1, p. 103-116.

McRoberts, E.C., and Morgenstern, N.R., 1974, The stability of thawing slopes: Canadian Geotechnical Journal, v. 11, p. 447-469.

Minard, J.P., 1964, Geology of the Roosevelt quadrangle, New Jersey: U.S. Geological Survey Geologic Quadrangle Map GQ-340, scale 1:24,000.

1965, Geologic map of the Woodstown quadrangle, Gloucester and Salem Counties, New Jersey: U.S. Geological Survey Geologic Quadrangle Map GQ-404, scale $1: 24,000$.

1969, Geology of the Sandy Hook quadrangle in Monmouth County, New Jersey: U.S. Geological Survey Bulletin 1276, 43 p., 1 plate, scale 1:24,000. 
Minard, J.P., and Owens, J.P., 1962, Pre-Quaternary geology of the New Egypt quadrangle, New Jersey: U.S. Geological Survey Geologic Quadrangle Map GQ-161, scale 1:24,000.

1963, Pre-Quaternary geology of the Browns Mills quadrangle, New Jersey: U.S. Geological Survey Geologic Quadrangle Map GQ-264, scale 1:24,000.

Minard, J.P., Owens, J.P., and Nichols, T.C., 1964, PreQuaternary geology of the Mount Holly quadrangle, New Jersey: U.S. Geological Survey Geologic Quadrangle Map GQ-272, scale 1:24,000.

Minard, J.P., and Rhodehammel, E.C., 1969, Quaternary geology of part of northern New Jersey and the Trenton area, in Subitzky, Seymour, ed., Geology of selected areas in New Jersey and eastern Pennsylvania and guidebook of excursions: New Brunswick, N.J., Rutgers University Press, p. 279-313.

Mixon, R.B., 1985, Stratigraphic and geomorphic framework of uppermost Cenozoic deposits in the southern Delmarva Peninsula, Virginia and Maryland: U.S. Geological Survey Professional Paper 1067-G, 53 p.

Mixon, R.B., Berquist, C.R., Jr., Newell, W.L., Johnson, G.H., Powars, D.S., Schindler, J.S., and Rader, E.K., 1989, Geologic map and generalized cross sections of the Coastal Plain and adjacent parts of the Piedmont, Virginia: U.S. Geological Survey Miscellaneous Investigations Series Map I-2033, scale 1:250,000.

Mixon, R.B., Szabo, B.J., and Owens, J.P., 1982, Uraniumseries dating of mollusks and corals, and age of Pleistocene deposits, Chesapeake Bay area, Virginia and Maryland: U.S. Geological Survey Professional Paper 1067-E, 18 p., 2 plates.

Neumann, R.P., 1980, Evidence for pre-Wisconsinan (Jerseyan?) glacial deposits in the Rocky Hill-Kingston area, New Jersey: New Jersey Academy of Science Bulletin, v. 25, no. 1, p. 12-17.

Newell, W.L., Powars, D.S., Owens, J.P., and Schindler, J.S., 1995, Surficial geologic map of New Jersey, southern sheet: U.S. Geological Survey Open-File Report 95-272, scale $1: 100,000$.

Newell, W.L., and Wyckoff, J.S., 1992, Paleohydrology of four watersheds in the New Jersey Coastal Plain, in Gohn, G.S., ed., Proceedings of the 1988 U.S. Geological Survey workshop on the geology and geohydrology of the Atlantic Coastal Plain: U.S. Geological Survey Circular 1059, p. 23-28.

Newell, W.L., Wyckoff, J.S., Owens, J.P., and Farnsworth, John, 1989, Cenozoic geology and geomorphology of southern New Jersey coastal plain, Southeast Friends of the Pleistocene, 2nd annual field conference, November 11-13, 1988, Field trip guidebook: U.S. Geological Survey OpenFile Report 89-159, 51 p.

Owens, J.P., Bybell, L.M., Paulachok, Gary, Ager, T.A., Gonzalez, V.M., and Sugarman, P.J., 1988, Stratigraphy of the Tertiary sediments in a 945-foot-deep corehole near Mays Landing in the southeastern New Jersey Coastal Plain: U.S. Geological Survey Professional Paper 1484, 39 p.

Owens, J.P., and Denny, C.S., 1978, Geologic map of Worcester County: Baltimore, Maryland Geological Survey, scale 1:62,500.

1979a, Geologic map of Wicomico County: Baltimore,
Maryland Geological Survey, scale 1:62,500.

-1979b, Upper Cenozoic deposits of the central Delmarva Peninsula, Maryland and Delaware: U.S. Geological Survey Professional Paper 1067-A, 28 p.

Owens, J.P., Hess, M.M., Denny, C.S., and Dwornik, E.J., 1983, Postdepositional alteration of surface and nearsurface minerals in selected Coastal Plain formations of the middle Atlantic States: U.S. Geological Survey Professional Paper 1067-F, $45 \mathrm{p}$.

Owens, J.P., and Minard, J.P., 1962, Pre-Quaternary geology of the Columbus quadrangle, New Jersey: U.S. Geological Survey Geologic Quadrangle Map GQ-160, scale 1:24,000.

1964a, Pre-Quaternary geology of the Bristol quadrangle, New Jersey-Pennsylvania: U.S. Geological Survey Geologic Quadrangle Map GQ-342, scale 1:24,000.

1964b, Pre-Quaternary geology of the Pemberton quadrangle, New Jersey: U.S. Geological Survey Geologic Quadrangle Map GQ-262, scale, 1:24,000.

-1964c, Pre-Quaternary geology of the Trenton East quadrangle, New Jersey-Pennsylvania: U.S. Geological Survey Geologic Quadrangle Map GQ-341, scale 1:24,000.

-1966, Pre-Quaternary geology of the Allentown quadrangle, New Jersey: U.S. Geological Survey Geologic Quadrangle Map GQ-566, scale 1:24,000.

1975, Geologic map of the surficial deposits in the Trenton area, New Jersey and Pennsylvania: U.S. Geological Survey Miscellaneous Investigations Series Map I-884, scale 1:48,000.

1979, Upper Cenozoic sediments of the lower Delaware Valley and the northern Delmarva Peninsula, New Jersey, Pennsylvania, Delaware, and Maryland: U.S. Geological Survey Professional Paper 1067-D, $47 \mathrm{p}$.

Owens, J.P., Sugarman, P.J., Sohl, N.F., and Orndorff, R.C., 1995, Geologic map of New Jersey: Southern sheet: U.S. Geological Survey Open-File Report 95-254, 46 p., scale $1: 100,000$.

Owens, J.P., Sugarman, P.J., Sohl, N.F., Parker, R.A., Houghton, H.F., Volkert, R.A., Drake, A.A., Jr., and Orndorff, R.C., 1995, Geologic map of New Jersey: Central sheet: U.S. Geological Survey Open-File Report 95-253, 61 p., scale 1:100,000.

Owens, J.P., Sugarman, P.J., Sohl, N.F., Parker, R.A., Houghton, H.F., Volkert, R.A., and Drake, A.A., Jr., compilers; Orndorff, R.C., ed.; and Bybell, L.M., Andrews, G.W., Bukry, David, Zapecza, O.S., Paulachok, G.N., and Mullikin, Lloyd, contributors, 1998, Bedrock geologic map of central and southern New Jersey: U.S. Geological Survey Geologic Investigations Series I-2540-B, scale 1:100,000.

Rachele, L.D., 1976, Palynology of the Legler lignite: A deposit in the Tertiary Cohansey Formation of New Jersey, U.S.A.: Review of Paleobotany and Palynology, v. 22, p. 225-252.

Ramsey, K.W., 1993, Geologic map of the Milford and Mispillion River quadrangles: Delaware Geological Survey Geologic Map Series No. 8, scale 1:24,000.

Richards, H.G., and Harbison, Anne, 1942, Miocene invertebrate fauna of New Jersey: Proceedings of the Academy of Natural Sciences of Philadelphia, v. 94, p. 167-250.

Salisbury, R.D., 1902, Map showing the distribution of the 
glacial drift of New Jersey, plate 28 in The glacial geology of New Jersey: New Jersey Geological Survey Final Report, v. 5,802 p., scale $1: 316,800$.

Salisbury, R.D., and Knapp, G.N., 1917, The Quaternary formations of southern New Jersey: New Jersey Geological Survey Final Report, v. 8, 218 p.

Sirkin, L.A., Owens, J.P., Minard, J.P., and Rubin, Meyer, 1970, Palynology of some Upper Quaternary peat samples from the New Jersey Coastal Plain: U.S. Geological Survey Professional Paper 700-D, p. 77-87.

Stone, B.D., Stanford, S.D., and Witte, R.W., 1995, Surficial geologic map of the northern sheet, New Jersey: U.S. Geological Survey Open-File Report 95-543-B, 59 p., scale $1: 100,000$.

in press, Surficial geologic map of northern New Jersey:

U.S. Geological Survey Miscellaneous Investigations Series Map I-2540-C, scale 1:100,000

Sugarman, P.J., and Owens, J.P., 1994, Geologic map of the
Asbury Park quadrangle, Monmouth and Ocean Counties, New Jersey: New Jersey Geological Survey Geologic Map Series GMS 94-2, scale 1:24,000.

Sugarman, P.J., Owens, J.P., and Bybell, L.M., 1991, Geologic map of the Adelphia and Farmingdale quadrangles, Monmouth and Ocean Counties, New Jersey: New Jersey Geological Survey Geologic Map Series GMS 91-1, scale 1:24,000.

Washburn, A.L., 1980, Geocryology, a survey of periglacial processes and environments: New York, John Wiley and Sons, $406 \mathrm{p}$.

Wyckoff, J.S., and Newell, W.L., 1992, Silcrete near Woodstown, New Jersey, in Gohn, G.S., ed., Proceedings of the 1988 U.S. Geological Survey workshop on the geology and geohydrology of the Atlantic Coastal Plain: U.S. Geological Survey Circular 1059, p. 39-43.

Zapecza, O.S., 1989, Hydrogeologic framework of the New Jersey Coastal Plain: U.S. Geological Survey Professional Paper 1404-B, 49 p., 24 plates.

\section{DESCRIPTION OF MAP UNITS FOLLOWS}




\section{DESCRIPTION OF COASTAL PLAIN MAP UNITS}

[Grain sizes listed in order of decreasing abundance. On map, queried map-unit symbols indicate uncertainty.]

\section{MANMADE DEPOSITS}

$\mathrm{cb}$

Cranberry bog-Manmade dikes, bogs, canals, and reservoirs engineered for the seasonal flooding and draining of cranberry agriculture. Sand and peat; minor gravel; very well sorted, leached quartz and chert gravel; and fresh-water peat. Located in swampy flood plains of watersheds with abundant, base-flow discharge; bog surfaces are dressed during construction with 1 to $2 \mathrm{~m}$ of sand and peat excavated from nearby sources. Most extensively developed in broad, swampy bottom lands generally underlain by sandy, marine-shelf facies of Miocene Cohansey Formation or extensive surficial deposits derived from it

af

Artificial fill-Widely variable, unconsolidated aggregate of excavated materials that have been graded and compacted for site-specific engineering works. Highly variable thickness, ranging from a few $\mathrm{cm}$ up to $15 \mathrm{~m}$. Landfills and waste sites may be thicker

ds

Dredge spoil-Widely variable unconsolidated aggregates of sediments dredged, pumped, and discharged into settling ponds behind manmade levees; commonly deposited on top of extensive saltmarsh flats where it drains, compacts, leaches, and oxidizes. Most extensive along the Delaware River navigation channel and Inner Coastal Waterway. Thickness is commonly 3 to $6 \mathrm{~m}$

amt Ilmenite mine and pit spoil (titanium dioxide)

amg Glass sand mine and pit spoil (silica)-Sand, gravel, silt, and clay; dredged, washed, and discharged tailings. Area of active excavation and fill subject to change

amsg Sand and gravel pit spoil

amc Claypit spoil

\section{MODERN DEPOSITS}

$\mathrm{Qb}$ beaches have manmade beach replenishment operations which include dredging and pumping of sediments from channels and shallow offshore bars. Also includes active windblown sand deposits on Delaware Bay shoreline of Cape May and on undeveloped parts of barrier islands

Alluvium (Holocene)-Gray and brown sand, silt, pebble gravel, clay, cobbles, and boulders; minor peat and shells. Clastics are dominantly resistant, reworked, multicycle deposits derived from weathered uplands. Locally, concentrations of polished to disintegrated, weathered glauconite and distinctive kaolinite occur a short distance downstream from eroded outcrops of Cretaceous and Paleogene units. Deposits underlie flood plain, with channel bottoms of coarse lag gravel. Fining-upward sequences of trough crossbeds include woody and peaty fragments. Generally less than $3 \mathrm{~m}$ thick, except in largest rivers. Beneath Delaware River (below Delaware Memorial Bridge on southern sheet), bridge borings and seismic data indicate thickness is as much as $30 \mathrm{~m}$. These channel deposits generally have a basal gravelly sand which may be equivalent to outwash sands and gravels exposed at Fall Line near Trenton (Ordl, Ovl). Basal gravelly sand generally is less than $3 \mathrm{~m}$ thick, overlain by as much as $46 \mathrm{~m}$ of organic-rich, clayey silt sporadically interbedded with fine to very fine sand and shelly sand. Includes barrier-lagoonal complex shown only in cross sections of southern sheet

Om Salt-marsh deposits (Holocene to Pleistocene)Organic muck and peat, silt, clay, and sand. Black, brown, and gray organic muck includes remains of salt-tolerant grasses, especially Spartina (sp.). Silt and sand occur as levee and crevasse splay deposits along tidal creek margins. Transported largely as suspended sediments in turbid bays or rivers during high tides. Generally 1 to $2 \mathrm{~m}$ thick; up to $6 \mathrm{~m}$ thick along shorelines

Swamp deposits (Holocene to Pleistocene)Organic muck and peat, sand, silt, cobbles, and boulders. Black, brown, and gray organic muck and peat consisting of leaves, stems, and woody parts of grasses and trees from freshwater flood plains. Swamps commonly occur where shallow ground water intercepts surface. Deposits may overlie fluvialchannel and flood-plain deposits. Locally, swamps may include alluvial fans at mouths of creeks and colluvium and windblown sand along valley wall margins. Thickness is generally less than $2 \mathrm{~m}$ but locally may exceed $6 \mathrm{~m}$

\section{EOLIAN DEPOSITS}

Qe Dune field deposits (Holocene to Pleistocene)Yellow, white, tan, and gray, coarse- to fine-grained sand and silt. Includes well-rounded, very well sorted, frosted grains of quartz and locally derived minerals, including glauconite and mica 
MARGINAL-MARINE DEPOSITS (WARM CLIMATE, HIGH SEA LEVEL)

\section{Cape May Formation (Pleistocene)}

$\mathrm{Qcm}_{1} \quad$ Unit 1 (early Wisconsinan? to late Sangamonian)Quartz-rich sand with variable mix of heavy minerals; also includes gray, greenish-gray, olive-gray, brown, grayish-brown, tan, and white pebble gravel, quartz and chert, clayey silt, and peat. Sorting, clast shape, and bed forms indicate deposition in marginal-marine to estuarine environments. Beach deposits are distinguished by well-rounded disc- and rod-shaped pebbles; well-sorted, low-angle, planar beds dip seaward and are interleaved with sets of lunate megaripples and trough crossbeds which dip shoreward. Local exposures of beach deposits include leached, oxidized molds and casts of surf clams (Spisula, sp.); burrows also common. Estuarine deposits are distinguished by fining-upward couplets of crossbedded sand and laminar clayey silt with burrows and woody fragments. Much of unit is thin, residual, washed-lag deposit, generally 1 to $5 \mathrm{~m}$ thick

$\mathrm{Qcm}_{2}$ Unit 2 (late Sangamonian)-Sand, pebble gravel, clayey silt, peat, silty sand, and cobble gravel. Variety of oxidized colors including gray, greenish gray, and brownish gray. Deposits include facies of several depositional environments. Beach facies consists of quartz-rich sand to pebble gravel with variable mix of heavy minerals and chert; characterized by wellrounded, disc- and rod-shaped pebbles scattered in well-sorted, low-angle, planar beds which dip seaward and are interleaved with sets of lunate megaripples and trough crossbeds; axes of troughs parallel beach; locally includes leached, oxidized molds and casts of surf clams (Spisula, sp.); burrows common; top 1 to $2 \mathrm{~m}$ is deeply weathered and locally includes frost wedges and blanket of windblown sand; thickness varies from one to several meters; unconformably overlies open-bay to inner-shelf facies and largely is restricted to top 3 to $5 \mathrm{~m}$ of Cape May Peninsula south of Swainton in southern New Jersey. Shallowmarine facies consists of fine to medium sand and silty sand; includes scattered thin, shelly sand beds; patchy distribution, thin layers, and lack of good subsurface data makes separation of this facies from estuarine-fluvial facies difficult. Estuarine-fluvial facies consists of sand, pebble to cobble gravel, silt and clay, and peat; deposits localized along tributary rivers entrenched primarily into Cohansey and Kirkwood Formations in southern New Jersey

Qcmbl Barrier-lagoon facies (late Sangamonian)-Mapped only on Cape May Peninsula in southern New Jersey. Consists of quartz-rich sand, clayey silt, pebble gravel, and peat with variable component of heavy minerals and chert; characterized by finingupward couplets of crossbedded sand and laminar clay and silt with burrows and wood fragments. Surface morphology characterized by closed depressions (thermokarst) superimposed on paleo- inlets which cross Cape May Peninsula to Delaware Bay. Thickness varies; locally is as much as 4 to 5 $\mathrm{m}$; thickness of sand bars along ocean-facing side of Cape May Peninsula may exceed $7 \mathrm{~m}$

$\mathrm{Qcm}_{3} \quad$ Unit 3 (early Sangamonian)-Sand, clayey silt, pebble gravel, and peat; wide variety of oxidized colors including gray and brownish gray. Primarily consists of quartz-rich estuarine and fluvial deposits with variable amounts of heavy minerals and chert. Thickness is highly variable, ranging from 1 to $47 \mathrm{~m}$; thicker deposits fill deep channels cut as much as 55 $\mathrm{m}$ below present sea level by paleorivers, including a proto-Delaware River channel described by Knebel and Circé (1988) and Knebel (1992). Channels formed when sea level dropped as much as $60 \mathrm{~m}$ below present sea level. Paleochannel shown in cross section $C-C^{\prime}$ on southern sheet has been informally known as the Rio Grande paleochannel (Gill, 1959, 1962a,b)

Qcmb Beach-barrier facies (early Sangamonian)-Sand and pebble gravel; wide variety of oxidized colors; includes quartz-rich sand and well-rounded, disc- and rod-shaped pebbles with variable mix of heavy minerals and chert. Well-sorted, low-angle, planar beds that dip seaward are interleaved with sets of lunate megaripples and trough crossbeds which dip shoreward; long axes of troughs parallel beach. Locally, deposits exhibit leached to oxidized molds and casts of surf clams (Spisula, sp.). Burrows are common. Bar morphology defines old barrier islands, paleo-inlets, and ebb-tide deltas. Deep weathering and illuviation of clay and oxides several meters below surface distinguish long exposure this unit experienced compared with younger, similar marginal-marine deposits $\left(\mathrm{Qcm}_{1}, \mathrm{Ocm}_{2}\right)$. Thickness generally less than $10 \mathrm{~m}$, but ranges up to $25 \mathrm{~m}$; surface altitudes as high as $11 \mathrm{~m}$. Represents culmination of sea-level rise during earliest transgressive-regressive cycle. In southern New Jersey, unit is distinctive on upland surfaces of Cape May Peninsula. In central New Jersey, unit is mapped between Long Branch and Asbury Park

Ocm Cape May Formation, undivided (early Wisconsinan? to early Sangamonian)-Shown where not enough information was available to distinguish separate sequences within Cape May Formation. Shown in Delaware River valley and in Atlantic Coast-facing deposits on sheet 1 . Locally, barrier bars are distinguished by an overprint pattern. Unit appears in the subsurface on the cross sections (sheet 3). May also include fluvial deposits at Van Sciver Lake (OvI) and fluvial deposits at Spring Lake (QsI)

\section{FLUVIAL DEPOSITS (COLD CLIMATE, LOW SEA LEVEL)}

Ovl Fluvial deposits at Van Sciver Lake (Graywacke 1 of Owens and Minard, 1975; Van Sciver Lake beds of Owens and Minard, 1979) (late Wisconsinan)Predominantly interstratified sand and gravelly sands 
that become finer down Delaware River valley in central New Jersey. Surface altitudes of deposits south of Trenton range from 4.5 to $9 \mathrm{~m}$ above sea level, and as high as $12 \mathrm{~m}$ northwest of Trenton. Upper $1.8 \mathrm{~m}$ of deposits typically pale-red, paleyellowish-brown, or grayish-orange, thin-bedded, horizontally bedded silt to very fine sand, commonly with thin gravel layer at base. Lower beds commonly light-medium-gray interstratified sand and gravelly sand as much as $12 \mathrm{~m}$ thick. Gravel abundant and unweathered; boulders as much as $1.8 \mathrm{~m}$ in diameter common. Layering typically includes horizontally stratified gravelly sand and cross-stratified sand. Sand contains dark rock fragments as a major constituent; may be compositionally considered a high-rank graywacke (Krynine, 1948). In contrast with older, higher deposits, gravels at this level contain limestone pebbles and cobbles. Leaching, however, is typical in upper 1.8 to $2.4 \mathrm{~m}$; below those depths, pebbles are commonly coated or, rarely, cemented by calcium carbonate. Other types of gravel include quartzite, quartz, and red Triassic sandstone and shale. Age is conjectural because no datable materials have been found. Apparently grades to Delaware River outwash of Rockaway Formation (Ordl) in this report and in Stone and others (1995, in press). If that continuity is correct, age is late Wisconsinan. Description adapted from Owens and Minard (1975)

Fluvial deposits at Spring Lake (Graywacke 2 of Owens and Minard, 1975; Spring Lake beds of Owens and Minard, 1979) (Sangamonian)-Similar in texture and composition to fluvial deposits at Van Sciver Lake (Qvl). Largely interstratified sand and gravelly sand, but at higher elevations in central New Jersey. Terrace surfaces extensively dissected, but range in altitude from $12 \mathrm{~m}$ near Bristol to $21 \mathrm{~m}$ beneath and northwest of Trenton. Upper beds typically thin $(2.54 \mathrm{~cm})$ to thick $(1.5 \mathrm{~m})$ and consist of horizontally stratified silt and very fine sand similar in color to upper beds of Qvl. Lower beds thickest (as much as $9 \mathrm{~m}$ ) and consist of interstratified, poorly crossbedded sand and horizontally bedded, gravelly sand. Beds are also distinctly redder (pale red to grayish red) than Qvi. More oxidized, moderate-reddish-orange gravels as much as $6 \mathrm{~m}$ thick occur at base. Gravel is very abundant and contains quartzite, vein quartz, crystalline rocks, and Triassic sandstone, argillite, and shale. Feldspar-bearing gravel appears more weathered than comparable gravels in Ovl, particularly in basal reddish-orange beds. Sands have generally same graywacke composition as those in Ovl except in basal reddish-orange beds which have much more feldspar than rock fragments and are therefore an arkose. Age of deposits unknown, but they are certainly older than lower terraces underlain by Ovl which crop out along Delaware River valley northwest of Trenton. Long hiatus between deposition of Ovl and Osl suggested because Ovl cuts across and is entrenched below Osl. Osl is also more deeply weathered

\section{WEATHERED MATERIALS AND TERRESTRIAL DEPOSITS}

\section{Slope and valley deposits}

Oca $_{1}$ Colluvium and alluvium unit 1 (Pleistocene)-Sand, gravel, silt, clay, and rare peat and wood. Sediments dominantly quartz rich with variable amounts of heavy minerals, glauconite, chert, and clasts from ironstone-cemented horizons; variability depends on proximity to source materials, weathering history, and multicyclic transport history. Colluvium is generally poorly sorted with matrix-supported clasts and discontinuous pebble layers common at the base. Deposits underlie gentle slopes and merge with alluvium in valley bottoms. Alluvium is moderately sorted and deposited in sets of planar beds or trough crossbeds which fill old channels and gullies, or alternatively as alluvial fans interbedded with colluvium. Underlies low slopes and some valley bottoms; generally continuous across broad areas. Thickness generally 0.5 to $1.5 \mathrm{~m}$; locally may exceed $3 \mathrm{~m}$. Soil development (including lamellae) minimal and largely limited to accumulations of humate and local development of chromic B horizons

$\mathrm{Qca}_{1 \mathrm{~b}}$ Braided-channel deposits (Pleistocene)-Sand, gravel, and peat. Well-rounded quartz, heavy minerals, and chert clasts in complex trough crossbeds which underlie gently sloping alluvial plain surfaces engraved with anastomosing, braided channels. Channels are 1 to $2 \mathrm{~m}$ deep and less than $10 \mathrm{~m}$ wide. Thickness commonly is 1 to $4 \mathrm{~m}$, but may be as much as $6 \mathrm{~m}$. Most extensive in area between Atsion and Batsto and in uplands northeast of Mullica River valley in southern New Jersey (Farrell, 1983; Newell and Wyckoff, 1992)

Oca $_{1 \mathrm{~d}}$ Debris-flow and alluvial-fan deposits, undivided (Pleistocene)-Sand, gravel, peat, minor silt, and clay. Quartz-rich sediments with variable heavymineral and chert clasts occur as unsorted colluvium and poorly sorted, laminar-bedded deposits at mouths of tributary valleys intersecting braided-channel alluvial plain. Along Atlantic Coast, where small valleys intersect prominent east-facing late Pleistocene (late Sangamonian) wave-cut scarp, alluvial-fan deposits form apron over beds of unit 1 of Cape May Formation $\left(\mathrm{Ocm}_{1}\right)$. Thickness generally less than $2 \mathrm{~m}$ but may locally reach $6 \mathrm{~m}$. Mapped only in southern New Jersey

$\mathrm{Oca}_{2}$ Colluvium and alluvium unit 2 (Pleistocene)Materials and sorting identical to $\mathrm{Qca}_{1}$, but surficial deposit is more weathered and soil profiles exhibit deep textural B horizons; top of unit may include thin layer of windblown sand. Congeliturbation features and frost wedges are common within this and older slope deposits. Materials derived from older, preexisting slope deposits as well as sediment eroded directly from underlying bedrock units. Unit is generally less than $2 \mathrm{~m}$ thick but may range to $8 \mathrm{~m}$ 
$\mathrm{Qca}_{3} \quad$ Colluvium and alluvium unit 3 (Pleistocene)Materials and sorting identical to Oca ${ }_{1}$; weathering, soil development, and frozen-ground phenomena similar to $\mathrm{Oca}_{2}$; more completely developed through entire thickness of deposit. Thickness generally less than $2 \mathrm{~m}$, but may range up to $8 \mathrm{~m}$. Commonly occurs as erosional remnants capping minor divides between evolving drainages. Source of reworked sediment for younger slope deposits

$\mathrm{Oca}_{4}$ Colluvium and alluvium unit 4 (Pleistocene)Materials, sorting, thickness, weathering, and frozenground phenomena identical to younger slope deposits. At some localities, nearly all of original surficial deposit has been stripped off; especially common where old higher erosional remnants overlie a clay to silt substrate

$\mathrm{Oca}_{5} \quad$ Colluvium and alluvium unit 5 (Pleistocene)-Same as $\mathrm{Oca}_{4}$, but is distinguished only in southern New Jersey in the headwaters of Alloway Creek and the Salem River

OTcau Colluvium and alluvium, undivided (Pleistocene to Miocene) - Sand, silt, pebble gravel, clay, boulders. Sand is medium fine to coarse, dominantly quartz, with distinctive mix of feldspar grains and heavy minerals; grains have been etched and deeply altered. Glauconite content varies from a trace to dominant depending on proximity to Cretaceous and Paleogene sources. Thickness of unit ranges from feather edge to as much as $12 \mathrm{~m}$. Alluvium includes trough crossbed sets of variable thickness. Deep oxidation throughout unit; clay residuum from destruction of unstable minerals at top of exposures is illuviated deep in the deposit. Unconformably overlies older Coastal Plain sediments. Top surface covered with thin, windblown sediments, colluvium, or congeliturbated horizons (characterized by homogenized horizon of unsorted, matrix-supported clasts). Restricted to high benches flanking Delaware River valley from Palmyra to Swedesboro in central New Jersey and farther south around margin of upper Delaware Bay to uplands behind Cedarville and Newport in southern New Jersey. May have marginal affinities to fluvial deposits of Pensauken Formation

\section{Hilltop regolith}

Leached residuum of the Freehold uplands (Quaternary and Tertiary)-Erosional remnants of hills cut into Redbank Formation and Hornerstown Formation (Owens, Sugarman, Sohl, Parker, and others, 1995; Owens and others, 1998) preserve residuum that is leached and oxidized debris of those formations. Deeply oxidized and locally cemented by limonite from destruction of glauconite. Indurated Tinton Formation (Owens, Sugarman, Sohl, Parker, and others, 1995; Owens and others, 1998) may locally be part of regolith cap. Locally includes transported material that is leached or indurated
QTrw Leached residuum at Warrens Grove (Quaternary and Tertiary) - White to orange to bright-red gravel, sand, silt, and clay, with yellow-red, oxide-stained, siliceous gravels in random matrix. Gravel consists of quartz, polycrystalline quartz, and Paleozoic chert with deeply etched surfaces; chert may be chalky, broken, and etched along fractures. Quartz sand also includes primarily ilmenite and resistant heavy minerals (zircon, rutile, tourmaline). Silt consists of windblown particles and silica-rich microshards from solution etching and spalling of large quartz clasts. Clay is primarily kaolinite with locally abundant gibbsite. Quartz and chert clasts occur as bleached lag gravel 10 to $30 \mathrm{~cm}$ thick armoring upland summits against erosion. Illuviated horizon is commonly indicated by enrichment of clay and silt 1 $\mathrm{m}$ or more below surface. Locally includes younger windblown silt and sand from lower slopes and valleys. Unit occurs on deeply leached uplands overlying upper delta-front facies of Cohansey Formation (Tchd) and on erosional remnants of channel gravels along watershed divide between streams draining into either Delaware Bay or Atlantic Ocean in central New Jersey. Also occurs on some broad erosional remnants of the proximal basal fluvial to marine gravels of the Cohansey along the northern margin of Cohansey outcrop

Ts Silcrete (Tertiary)-Boulders and cobbles. May locally outcrop as a "hard bed" or cap on low hills. Residual clasts and cap of silica-cemented paleosol form a duricrust capping low hills (Wyckoff and Newell, 1992) along outcrop belt of interface between "Alloway clay" and "Grenloch sand" (Isphording and Lodding, 1969). Materials are scattered on surface and in shallow subsurface on hills and slopes near Swedesboro

\section{MARINE, MARGINAL-MARINE, ESTUARINE, DELTAIC, AND FLUVIAL DEPOSITS}

Tu Unnamed unit beneath Cape May Peninsula (upper Pliocene?)-Gray to greenish-gray to black, thin- to thick-bedded $(0.3$ to $6 \mathrm{~m})$ sand; clayey, silty sand; glauconitic, pebbly sand; and woody, clayey silt. Found only in subsurface beneath Cape May Peninsula. Lithic and palynological analysis of corehole data at Cape May County Airport indicates that unit occurs as 30 -m-thick (at -50 to $-80 \mathrm{~m}$ before present sea level) sequence of ascending fluvial, estuarine, and marine upper Pliocene(?) deposits bounded by unconformities. Basal unconformity marked by gravelly sand overlying well-sorted, silty, fine sand with diatoms from Belleplain Member of Kirkwood Formation (Owens, Sugarman, Sohl, and Orndorff, 1995; Owens, Sugarman, Sohl, Parker, and others, 1995; Owens and others, 1998). Quartz and siliceous rock fragments dominate sand fraction; less than 10 percent is feldspar. Lower fluvial to estuarine deposits contain abundant hornblende and garnet, while upper marine deposits contain 
abundant zircon, tourmaline, and rutile. Age based on low percentages of exotic pollen found within section from Cape May County Airport corehole; exotic pollen includes Sciadopitys, Engelhardia, Tricolporopollenites, and a Multisia-type composite (Groot, 1991; Leslie A. Sirkin, Adelphi University, written commun., 1991)

Tps Pensauken Formation (Pliocene? to upper Miocene?)-Sand, gravel, silt, clay, cobbles, and boulders. Orange to reddish-brown, angular to subrounded, coarse- to fine-grained, arkosic alluvium that includes quartz and chert, abundant weathered feldspar grains, and weathered, unstable heavy minerals and lithic fragments. Gravel, cobbles, and boulders include clasts of single crystalline and polycrystalline quartz, chert, gneiss, schist, quartzite, sandstone, and shale (Martino, 1981). Silt and clay are minor constituents, dominated by quartz and kaolin. Includes $0.5-$ to 1.5 -m-thick sets of planar trough crossbeds, planar beds, ripple trough crossbeds, and massive sand, gravel, silt, and clay. Assemblages of these bedding forms are commonly graded and arranged as finingupward sequences which record changing river dynamics and flood histories

Tbr Bridgeton Formation (Miocene)-Sand, gravel, silt, clay, cobbles, and boulders. Sand consists of arkosic, angular to poorly rounded grains of quartz, weathered feldspar, mica, and an immature suite of unstable and resistant heavy minerals including hornblende, epidote, garnet, tourmaline, magnetite, ilmenite, zircon, and rutile; gravel is quartz rich with abundant fossiliferous Paleozoic chert and less common rock fragments of great lithic diversity; cobbles and boulders consist of resistant polycrystalline quartz, Paleozoic quartzite and sandstone, granite gneiss, schist, metavolcanics, Triassic red beds, and Jurassic diabase (Martino, 1981). Many lithic clasts are completely weathered. Clay is predominantly kaolin from in-place weathering of feldspar-rich sediments and from erosion of weathered crystalline rocks in source areas. Mixed layers of illite and vermiculite also locally common. Many exposures exhibit deep, pervasive weathering which has leached most feldspars and unstable heavy minerals from sand grains and coarser lithic clasts. Reddish to orange hues common on weathered exposures. Liesegang banding and clay caps, bridges, and halos in thick, deeply weathered exposures indicate massive alteration and transport of silt, clay, and colloidal materials. Locally, weathering was pervasive, of long duration, and produced an insoluble residue containing abundant gibbsite. Exposures commonly show large-scale pluvial bedding (Newell and others, 1989). Crossbed sets are as much as 3 to $4 \mathrm{~m}$ thick. Sand and gravel of each foreset bed is graded but poorly packed, maximizing pore space. Bed forms are both planar and trough crossbeds with uniform sets from 0.5 to $1.0 \mathrm{~m}$ thick. Crossbeds generally indicate southeast vector consistent with pattern documented by Owens and Minard (1979). Base of Bridgeton is channeled into underlying units; throughout Southern Uplands, upper part of underlying Cohansey Formation is generally truncated. Relief on unconformity locally ranges from 1 to $5 \mathrm{~m}$. Large boulders are concentrated in basal beds

Tbrg Channel bar forms-Lithology and sorting same as above. Bar forms are excessively permeable, provide rapid infiltration of ground water, and have resisted surface erosion; they stand as erosional remnants above surface of Bridgeton outcrop belt with 3 to 10 $\mathrm{m}$ in local relief, several hundred meters in width, and 1 to $5 \mathrm{~km}$ in length. Deposits are composed mostly of unidirectional sets of coarse sand and gravel crossbeds as previously described. Upper beds may include ripple trough crossbeds, climbing ripples, and clay drapes about $1 \mathrm{~m}$ thick that indicate waning flow velocities. At some localities, top of permeable bar deposits is overlain by smaller scale fluvial deposits. Extreme permeability of unconsolidated sand and gravel lowers susceptibility to surface erosion. Smaller scale bed forms in upper part of Bridgeton include repeated fining-upward cycles of 1 to $2 \mathrm{~m}$ that include massive pebble gravels; imbricated, planar-bedded, and trough-crossbedded sands and gravels; and fine, ripple-bedded, and laminated sand and silt. Silt- to clay-sized sediments largely limited to overbank deposits on flood plains

Tch Cohansey Formation (Miocene)-Lower marine shelf to littoral sequence. Consists of sand, gravel, silt, clay, peat, and lignite. Sand consists of white, paleyellow, and gray, fine- to medium-grained, wellrounded, well-sorted, unweathered quartz and siliceous rock fragments; weathers to various shades of red, brown, orange, and white; locally indurated with limonite along bedding; liesegang bands are common. Gravel consists of very well rounded quartz and small, rounded, and broken Paleozoic chert clasts. Clay is predominantly kaolinite and illite. Opaque heavy minerals are mainly ilmenite and its weathering products, leucoxene and pseudorutile. These minerals occur in ore-grade concentrations near Lakehurst and were recently mined as source of titanium dioxide. Nonopaque heavy minerals include primarily a mixture of resistant zircon, tourmaline, rutile, and monazite. Somewhat less resistant minerals (staurolite, sillimanite, and kyanite) occur sparingly. Basal part of unit generally marked by quartz and chert pebble conglomerate lag that unconformably truncates several members of Kirkwood Formation. Elsewhere, extensive massive, fine-grained, well-sorted, quartz-rich sand (interpreted as a marine-shelf environment) extends from basal unconformity upwards tens of meters and locally includes extensive burrows (by many species) or beds that appear to be massive due to bioturbation. At many localities south of Mullica River in southern New Jersey (Newell and others, 1989) are assemblages of trough crossbeds interspersed with gently dipping, attenuated sets of planar beds 
(interpreted as marine beach deposits). Thickness ranges from 2 to $6 \mathrm{~m}$; beds consist of well-rounded, crossbedded sand and sparse pebbles, cemented molds and casts of shell hash (including clam Spisula, sp.), and deep, penetrating, noded, clay-lined burrows (Ophiomorpha nodosa). Alternating trough crossbeds and planar beds were created in surf zone and represent rising and falling tidal deposition and storm-surge events. Overlying beach facies are meandering channels filled with silt and clay, and small-scale $(10$ to $20 \mathrm{~cm}$ ) ripples, crossbeds, and planar beds indicative of tidal channels in back-barrier and lagoonal environments. Locally, south of Mullica River valley, deltaic channel deposits cut into and meander across marine to marginal-marine deposits similar to those near Millville in southern New Jersey. Across Southern Uplands, various portions of Cohansey sequence are truncated locally by unconformity at base of Bridgeton Formation (Tbr); most of upper deltaic sequence has been removed south of Mullica River valley. At some localities, Bridgeton rests upon Cohansey shelf deposits; at other localities, Bridgeton rests on littoral or deltaic Cohansey deposits

Tchd Upper delta-front facies-Fine to coarse sand, and gravel, silt and clay, peat and lignite; colors and mineralogy similar to the marine sequence (Tch)

Tchg Fluvial gravel facies-Sorting and lithology as above. North of Toms River in central New Jersey, isolated outcrops of Cohansey Formation include abundant gravel. Occurs at base of formation; unconformably overlies Kirkwood Formation (Tkw) and other older, underlying units. Although marine or estuarine deposits have been observed locally, gravel facies is dominantly fluvial, occurring along updip margins of the original depositional basin; some deposits may have been fluvial channel fillings that fed upper deltafront deposits (Tchd) to the south in Cohansey outcrop area

Tkw Kirkwood Formation (Miocene)-Sand, silt, and clay. Sand is medium to dark gray, dark grayish brown, or dark grayish green, very fine grained, quartz rich, distinctively micaceous, and locally diatomaceous; commonly weathers pinkish gray to light grayish orange. In exposures, commonly laminar bedded with micaceous, silty partings, 2 to $5 \mathrm{~mm}$ thick; bedding may be massive and bioturbated. Locally, Kirkwood includes extensive massive, gray to darkbrown silt to clay beds with characteristic micaceous partings and local lignite. Beds range from $10 \mathrm{~cm}$ to $5 \mathrm{~m}$ or more in thickness. Clay dominated by illitesmectite, illite, and kaolin typical of shallow-marine to delta-front depositional environments. Where it crops out, unit has been excavated for liner and cover material for landfills

\section{OLDER ROCKS}

TKu Marshalltown Formation to Shark River Formation, undivided (Upper Cretaceous to Eocene)-
Includes sand, silt, clay, gravels, and lignite of fluvial to marine cyclic deposits; mineralogy ranges from quartzose to glauconitic with clay minerals that include kaolinite, illite-smectite, and montmorillonite. Includes Englishtown, Marshalltown, Wenonah, Mount Laurel, Navesink, Red Bank, Tinton, Hornerstown, Vincentown, Manasquan, and Shark River Formations (Owens, Sugarman, Sohl, and Orndorff, 1995; Owens, Sugarman, Sohl, Parker, and others, 1995; Owens and others, 1998)

$\mathrm{Kw}$

Woodbury Formation (Upper Cretaceous)-Darkgray, impermeable swelling clay (see Owens, Sugarman, Sohl, and Orndorff, 1995; Owens, Sugarman, Sohl, Parker, and others, 1995; and Owens and others, 1998, for details). Subcrop pattern of unit mapped under surficial deposits from the outcrop pattern shown by Owens, Sugarman, Sohl, and Orndorff (1995); Owens, Sugarman, Sohl, Parker, and others (1995); and Owens and others, 1998. Outcrop pattern of unit important to distribution and preservation of subsequent surficial deposits

$\mathrm{Ku}$ Potomac Formation to Merchantville Formation, undivided (Upper Cretaceous)-Includes Potomac, Raritan, Magothy, Cheesequake, and Merchantville Formations (Owens, Sugarman, Sohl, Parker, and others, 1995; Owens and others, 1998)

PPzw Rocks of the Wilmington terrane (Paleozoic and Proterozoic)-Continental crust of undetermined origin. Granulite-facies assemblage of metasedimentary, metavolcanic, and intrusive rocks (Horton and others, 1991). Horton and others (1989) named this assemblage as a terrane and suggested amalgamation to Chopawamsic and Potomac terranes during the Taconian (Ordovician) or Penobscottian (Cambrian) events. Appears only in cross sections of southern New Jersey

\section{DESCRIPTION OF PIEDMONT MAP UNITS}

[Descriptions adapted from Stone and others (1995, in press). Map units are restricted to surficial materials more than $1 \mathrm{~m}$ thick that overlie bedrock. A veneer of colluvium less than $1 \mathrm{~m}$ thick covers most slopes and is not mapped. A discontinuous veneer of eolian fine sand to silt is present locally, but also is not mapped.]

\section{MANMADE DEPOSITS}

af Artificial fill-Earth and manmade materials artificially emplaced; includes gravel, sand, silt, clay, trash, cinders, and ash. Thickness ranges between 2 and $35 \mathrm{~m}$

amd Diabase quarry pit and tailings-Blocks of waste rock and sand, gravel, silt, and minor clay derived from crushed or pulverized rock that has been artificially emplaced 


\section{EOLIAN, ALLUVIAL, AND SLOPE DEPOSITS}

Qe

Eolian sand deposits (Holocene and Pleistocene, late Wisconsinan)-Light-brown to light-reddishbrown, very fine to medium sand and minor silt in continuous sheet deposits that mantle underlying materials; locally in dunes. Thickness 0.9 to $4.0 \mathrm{~m}$

Alluvium (Holocene and Pleistocene, late Wisconsinan)-Gravel, sand, silt, minor clay, and some organic material, deposited by modern streams. In flood plains of major rivers, alluvium commonly consists of poorly sorted gravel and sand at base, overlain by laminated and thinly bedded sand, silt, and clay; sand is moderately to poorly sorted. Thickness 1.8 to $9.1 \mathrm{~m}$. Along smaller streams, alluvium is composed of sand and gravel derived from adjacent glacial, meltwater, colluvial, or weathered-rock materials; sand and gravel is poorly sorted; thickness generally is less than $4 \mathrm{~m}$. Alluvium in Piedmont valley bottoms commonly includes swamp deposits too small to portray on map. In area of late Wisconsinan glacial deposits, alluvium locally includes and grades laterally into swamp and marsh deposits. In areas of older glacial deposits, colluvium, and weathered bedrock materials, alluvium locally grades into or intertongues with colluvium

Qalb Boulder-lag deposits (early Holocene and late Pleistocene, late Wisconsinan)-Diabase core stones in ravines and stone streams; distinguished by lack of matrix and topographic position. Locally transported from hill slopes and ravines underlain by diabase onto areas underlain by shale and siltstone. May have been transported by mass-wasting processes during cold climates; fine-grained matrix material subsequently eroded

Odi Alluvium at Duck Island (early Holocene and late Pleistocene, late Wisconsinan)-Compositionally similar to fluvial deposits at Van Sciver Lake (OvI), but with smaller scale, scoured and filled channels, pointbar deposits, and reworked finer grained material. Top of unit originally included fining-upward floodplain and overbank deposits. Underlies Duck Island and other nearby low (3 m elevation) islands downstream from Fall Zone in central New Jersey. Interpreted to be alluvium reworked from Delaware River valley outwash terraces (Ordl) by meteoric discharge during early Holocene. Currently, deposits are flooded during major storm events and finegrained sediments are veneered on surface. Much of Duck Island and other similar islands has been excavated for gravel and used for land fill, dredge spoil, and industrial sites

\section{TERRACE DEPOSITS}

Oml Millstone terrace deposits (early Holocene and late Pleistocene, late Wisconsinan)-Sand and gravel, sand, and silt; clasts are quartz, siltstone, sandstone, quartzite, gneiss, ironstone, and diabase; gneiss clasts generally nonweathered. Surface altitudes range from 14 to $13 \mathrm{~m}$. Thickness is as much as $12.2 \mathrm{~m}$. Includes some meltwater sediments

Ost Stream-terrace deposits (early Holocene and late Pleistocene, late Wisconsinan)-Moderately sorted sand with lesser amounts of gravel and silt; includes sediment derived from adjacent glacial, meltwater, weathered-rock, or colluvial materials. In terraces adjacent to flood plains of major rivers or in broad plains in lowland areas; deposited by meteoric (nonglacial meltwater) streams. Thickness 0.3 to $6.1 \mathrm{~m}$

of Alluvial-fan deposits (Pleistocene)-Poorly sorted gravel and sand with minor silt and organic material Fans commonly dissected by modern stream alluvium. Thickness as much as $12.2 \mathrm{~m}$

Qstu Upper stream-terrace deposits (Pleistocene)Description same as for Qst above. Deposits occur as isolated erosional remnants at various altitudes above Delaware and Raritan Rivers. Deposits too limited to interpret and may be either glacial or meteoric in origin

\section{COLLUVIAL DEPOSITS}

Silty sand, sandy silt, clayey silt, or gravelly sand deposits, consisting of very poorly to poorly sorted matrix of sand, silt, and clay (fig. $4 \mathrm{~b}$ of Stone and others, 1995). Commonly contains 5 to 60 percent (by volume) angular rock chips, tabular-shaped pebbles and cobbles, and small boulders; commonly massive to indistinctly layered, locally stratified, compact to loose, firm to hard consistency. Gravel clasts are subangular to angular and weathered; color and grain size are variable, reflecting composition of bedrock on higher slopes; local bedrock constitutes more than 95 percent of gravel clasts; contains few erratic gravel clasts in glaciated areas. Tabular gravel clasts have a strong slope-parallel fabric. Some clasts and aggregates have iron-manganese stain. Materials are gradational on slopes from (1) silty sand matrix with angular gravel, less than $2 \mathrm{~m}$ thick, on steep upper slopes, to (2) silty sand matrix with less than 40 percent pebbles and small cobbles, 2 to $3 \mathrm{~m}$ thick, to (3) compact silty sand matrix with less than 15 percent pebbles and a platy structure, and locally more than $9.1 \mathrm{~m}$ thick on lower slopes. Colluvium deposited on slopes by creep; shown where deposits form a continuous mantle on slopes over saprolite, residuum, or partly weathered bedrock. Units include thin beds and lenses of sorted and stratified sheetwash alluvial sand and gravel; thin, bouldery alluvial-fan deposits; sorted blocks and coarse sand debris-flow deposits; and minor beds of clay and silt. Units also include massive to indistinctly layered, very poorly sorted, silty, sparsely stony solifluction deposits and local boulder talus below steep bedrock outcrops. Units also include multiple colluvial deposits. Surface colluvium generally is composed of lightly weathered clasts; overlies local older colluvium containing weathered clasts and buried red soil profiles. Thickness ranges from 3.0 to $21.3 \mathrm{~m}$

Qcs Sandstone-, siltstone-, conglomerate-, or shale-clast colluvium (Holocene to Pleistocene)-Pale-red, to light-brownish-red, light-olive-brown, or reddishbrown silty sand or clayey silt matrix containing angular to subangular chips and tabular-shaped 
pebbles and cobbles of sandstone, siltstone, or shale. Poorly sorted, moderately compact, firm consistency. Conglomerate-clast colluvium contains subrounded, fractured pebbles and cobbles derived from weathered conglomerate. Unit includes minor laminated, poorly sorted sand and silt with lamination parallel to surface slope, as much as $1 \mathrm{~m}$ thick, of creep or possible solifluction origin. On its surface, unit also includes local rock rubble composed of partly weathered rock. Thickness ranges from 3.0 to $9.1 \mathrm{~m}$

Ocd Diabase-block colluvium (Holocene to Pleistocene)Reddish-yellow to brownish-yellow, sandy silt matrix containing angular to subangular, blocky boulders and cobbles of diabase. Poorly sorted, chiefly compact, firm consistency. Blocky gravel clasts have weathering rinds 0.2 to $1 \mathrm{~cm}$ thick. On its surface, unit includes local bouldery rubble of subrounded joint blocks of partly weathered rock. Thickness ranges from 1.8 to $5.2 \mathrm{~m}$

Ocb Basalt-block colluvium (Holocene to Pleistocene)Dark-gray, brown, yellowish-red to reddish-brown clayey silt to silty clay matrix containing angular to subangular blocky boulders and cobbles of basalt. Poorly sorted, chiefly compact, firm consistency. Blocky gravel clasts have weathering rinds 0.2 to 1 $\mathrm{cm}$ thick. On its surface, unit includes local bouldery rubble of subrounded joint blocks of partly weathered rock. Thickness ranges from 1.8 to $15.2 \mathrm{~m}$

Qcal Colluvium and alluvium, undifferentiated (Holocene to Pleistocene)-Thinly bedded silt, sand, and gravel. Discontinuously overlies and is interbedded with very poorly sorted colluvium. Sand and gravel is poorly sorted. Unit includes lag accumulations of blocks and cobbles on eroded colluvial surfaces or locally on weathered-rock materials. Thickness ranges from 0.3 to $6.1 \mathrm{~m}$

\section{GLACIAL MELTWATER DEPOSITS}

Mainly deposits of glacial streams. Interbedded sand and gravel, moderately to poorly sorted, horizontally stratified. Deposits grade from (1) coarse gravel facies in ice-proximal heads of units, to (2) sand and gravel facies, to (3) pebbly coarse sand facies in distal parts of some units. Coarse gravel facies consists of massive cobble gravel beds that have poorly sorted sand matrix; beds of small boulders common. Coarse gravel beds generally less than $1 \mathrm{~m}$ thick; beds composed of finer grained sediment rare. Sand and gravel facies is most prevalent; consists of pebble and cobble gravel beds interbedded with medium to coarse sand. Cobble gravel beds are massive or planar bedded, poorly to moderately sorted, and have local imbrication of clasts; pebble or cobble gravel beds also contain planar, tabular, and trough crossbeds. Gravel beds are 0.2 to $1.2 \mathrm{~m}$ thick. Sand beds are chiefly coarse sand with pebbles and granules, poorly sorted, in trough, planar, and tabular crossbeds. Ripple cross-laminated beds of medium and fine sand are minor constituents. Pebbly coarse sand facies consists chiefly of coarse sand with pebbles in trough, planar, and tabular crossbeds. Thin beds of pebble gravel are minor constituents. Glacial-stream deposits originated as outwash deposits that accumulated in promorainal or ice- marginal outwash plains across wide valley areas, and as valleytrain deposits, which are preserved as erosional terrace deposits that do not extend to ice-marginal heads of outwash (Stone and others, 1995; in press). Outwash-plain and valley-train terrace deposits have smooth downstream surface profiles. Glacialstream deposits overlie older alluvial deposits south of terminal moraine; distal terrace deposits contain sediments locally derived from nonglacial sources. Glacial-stream deposits generally 1.8 to $15.2 \mathrm{~m}$ thick, locally as much as $30.5 \mathrm{~m}$ thick

Ordl Delaware terrace deposits (of the Rockaway Formation; Stone and others, 1995, in press) (Pleistocene, late Wisconsinan)-Sand and gravel and pebbly sand. Surface altitudes slope from 98 to $46 \mathrm{~m}$. Thickness as much as $12.2 \mathrm{~m}$. Aggradation of sediments occurred proglacially in front of advancing ice sheet in upper Delaware River basin, and downstream from Foul Rift moraine deposit (unit Qkfrm of Stone and others, 1995, in press) during maximum glacial extent. Meltwater deposition in terraces continued during ice-margin retreat in the Wallkill and Delaware Rivers drainage basins in New York

Olbr Brainards outwash deposit (of the Lamington Formation; Stone and others, 1995, in press) (Pleistocene, Illinoian)-Sand and gravel of terrace deposit. Thickness as much as $6.1 \mathrm{~m}$. Surface altitudes in discontinuous terrace slope from $99 \mathrm{~m}$ to $67 \mathrm{~m}$. Unit includes local sand and gravel deposits with surface altitudes ranging from $122 \mathrm{~m}$ to $146 \mathrm{~m}$

Ops Stratified deposits (of the Port Murray Formation; Stone and others, 1995, in press) (Pleistocene, pre-Illinoian)-Reddish-yellow to strong brown sand and pebble-to-cobble gravel; gravel clasts are rounded to subangular; gravel clasts of carbonate rock and gneiss are deeply weathered to fully decomposed to depths of more than $3 \mathrm{~m}$; gravel clasts of chert and quartzite have thin weathering rinds; some gravel clasts have thin silt caps that adhere to their upper surfaces; gravel clasts of quartzite and quartzite conglomerate have a reddish-yellow iron-oxide stain; a black iron-manganese coating covers some gravel clasts. Weathered zone extends from the surface through entire deposit and into weathered rock. Deposited chiefly by glacial meltwater; some deposits also have been eroded and redeposited by alluvial and slope processes. Thickness generally less than 5.2 $\mathrm{m}$. Soils are alfisols with argillic B horizons, 0.4 to $1.3 \mathrm{~m}$ thick, overlying the $\mathrm{C}$ horizon in weathered sediment

\section{SAPROLITE, RESIDUUM, AND ROCK RUBBLE}

Silty sandy to clayey silty weathered-rock materials consisting of very poorly sorted or nonsorted matrix of sand, silt, and clay and 5 to 50 percent (by volume) angular pebbles and cobbles. Loose to compact, firm to hard consistency. Composition of gravel clasts is quartz, chert, or shale, which are resistant to weathering dissolution; partly weathered gravel clasts of local bedrock are in lower parts of saprolite and residuum and in thin colluvial deposits near land surface; few erratic gravel clasts are found at land surface in glaciated areas. Local color and grain 
size of matrix vary, reflecting composition and degree of weathering of underlying bedrock. Materials derived from inplace chemical weathering of underlying bedrock with no appreciable subsequent lateral transport. Materials include (1) sandy to clayey decomposition residuum consisting of homogeneous matrix and weathered angular gravel clasts, all derived from in-place weathering of clastic rock, and (2) silty sand to clayey structured saprolite composed of quartzose framework that preserves original rock structure and fabric and interstitial clay derived from weathering of feldspar and accessory minerals derived from crystalline rocks, quartzite, and quartz conglomerate. Zone of structureless saprolite, composed of quartz and clay produced by collapse and minor lateral creep of original saprolite framework, overlies structured saprolite. Local weathered-rock rubble, composed of subangular blocks of partly weathered rock, overlies partly weathered bedrock in areas of shallow rock on some ridge crests. Residuum and saprolite grade downward into partly weathered bedrock through a zone of weathered rock, which is composed of altered rock and ironmanganese coatings along joint planes or bedding, or alternating zones of rock and saprolite or residuum. Translocated clay fills some fractures in partly weathered rock. Map units include surface deposits of poorly sorted sandy or silty colluvium or solifluction debris on nearly all slopes greater than $3^{\circ}$ to $5^{\circ}$, thin alluvium, sheetwash deposits, and debris-flow deposits

Qsw Silty clayey to sandy silty sandstone, siltstone, and shale residuum; silty sandy quartzite and conglomerate; saprolite; and rock rubble (Holocene and Pleistocene)-Reddish-brown, nonsorted, compact, silty clay or sandy silt residuum containing 10 to 50 percent chips and tabular pebbles and cobbles of shale, siltstone, or sandstone. Thickness less than $1 \mathrm{~m}$ on ridges; as much as $3 \mathrm{~m}$, including colluvium, at bases of slopes. Unit includes light-olive-brown, nonsorted, compact, silty shale residuum containing 10 to 50 percent shale and flat pebbles of shale; nonsorted, compact; less than $2 \mathrm{~m}$ thick. Also includes local nonsorted, light-gray to white, structureless and structured quartzite saprolite; and reddish-brown, silty clay to very pale brown, sandy structureless and structured conglomerate saprolite containing 10 to 50 percent pebbles and cobbles of quartzite and weathered conglomerate. Thickness as much as $21.3 \mathrm{~m}$

Qdrh Diamicton at Rocky Hill (Pleistocene)-Sand, silt, clay, pebbles, cobbles, and boulders. Poorly sorted, matrix supported clasts capping uplands at Rocky Hill. Thickness may range from 1 to $5 \mathrm{~m}$. Scattered lag of exotic gravel and cobbles litters surface of deposits and surrounding slopes. Large clasts include rounded, broken, and weathered Paleozoic chert, quartzite, and sandstone derived from outcrops of Pensauken Formation (Tps) nearby to the south. Partly weathered, spheroidal cobbles and boulders of diabase also a significant component. Diabase clasts originated from Jurassic Rocky Hill diabase sill nearby to the south (Owens, Sugarman, Sohl, Parker, and others, 1995; Owens and others, 1998). Deep-red to orange matrix of fine-grained sediment is derived largely from underlying siltstone and shale of Triassic Brunswick Formation (Owens, Sugarman, Sohl, Parker, and others, 1995; Owens and others, 1998). This unit was mapped originally as erosional remnants of Pensauken Formation (Lewis and Kümmel, 1910-1912); more recently interpreted as outlier of very early Pleistocene till (Neumann, 1980). Underlies high-level terrace remnants deposited by north-flowing reach of ancestral Millstone River which drained across the Coastal Plain-Piedmont boundary. Lack of fluvial sorting and mixing of gravels with underlying fine-grained sediments to produce diamict texture is attributed to congeliturbation during multiple cold-climate cycles

QTdw Sandy silty diabase saprolite and rock rubble (Pleistocene to Miocene)-Nonsorted, brown to dark-brown, sandy to silty structureless saprolite containing 10 to 50 percent angular pebbles and cobbles of partly weathered diabase. Gravel clasts have weathering rinds 0.2 to $1 \mathrm{~cm}$ thick: Thickness as much as $6.1 \mathrm{~m}$. Overlies sandy silt structured saprolite, generally less than $2 \mathrm{~m}$ thick. Unit includes granular to blocky, weathered rock rubble with boulders, as much as $3.0 \mathrm{~m}$ thick

QTbw Clayey silty basalt saprolite and rock rubble (Pleistocene to Miocene)-Nonsorted, yellowish-red to reddish-brown to red, silty clay structureless saprolite, containing 10 to 50 percent angular pebbles and cobbles of partly weathered basalt. Gravel clasts have weathering rinds 0.2 to $1 \mathrm{~cm}$ thick. Thickness as much as $6.1 \mathrm{~m}$. Overlying silty clay structured saprolite, generally less than $2 \mathrm{~m}$ thick. Unit includes local granular to blocky, weathered rock rubble with boulders, as much as $3.0 \mathrm{~m}$ thick

\section{OLDER ROCKS}

Jku Bedrock (Jurassic and Triassic)-Exposed bedrock in quarries, other large excavations, and large natural outcrops; partly weathered along fractures near surface (Owens, Sugarman, Sohl, Parker, and others, 1995; Owens and others, 1998) 


